\title{
Digestion and nitrogen utilization in dairy heifers limit-fed a low or high forage ration at four levels of nitrogen intake ${ }^{1}$
}

\author{
G. I. Zanton and A. J. Heinrichs ${ }^{2}$ \\ Department of Dairy and Animal Science, The Pennsylvania State University, University Park 16802
}

\begin{abstract}
The hypothesis of this experiment is that a low-forage (LF) ration will be utilized with greater efficiency than a high-forage ration (HF) by dairy heifers and that the response will be affected by level of $\mathrm{N}$ intake. To test this hypothesis, 8 Holstein heifers (beginning at $362 \pm$ $7 \mathrm{~kg}$ and $12.3 \pm 0.4 \mathrm{mo}$ ) were fed 8 rations according to a split-plot, $4 \times 4$ Latin square design. Treatments were formulated to contain 25 or $75 \%$ forage (corn silage and chopped wheat straw) and fed at 4 levels of $\mathrm{N}$ intake [0.94 (Low), 1.62 (MLow), 2.30 (MHigh), 2.96 (High) g of $\mathrm{N} / \mathrm{kg}$ of metabolic body weight per day]. Diets were limit-fed to maintain equal intake of metabolizable energy. Blood samples were collected over d 19 to 20, and feces and urine were collected for $8 \mathrm{~d}$ per 28-d period. Organic matter $(\mathrm{OM})$ intake was greater for heifers fed $\mathrm{HF}$, but, due to increased OM digestibility of LF (74.0 vs. $67.6 \% \pm 0.9$ ), digestible OMI was unaffected by forage level. Organic matter digestibility was affected by an interaction between forage level and $\mathrm{N}$ intake, increasing to a plateau of $78.01 \%$ at $18.43 \%$ crude protein for LF-fed and $68.78 \%$ at $13.90 \%$ crude protein for HF-fed heifers. Apparent N digestibility was greater for heifers fed LF and increased from 47.7 to $80.8 \%$ between Low and High $\mathrm{N}$ intake. Less $\mathrm{N}$ appeared in the feces of heifers fed LF than HF (45.56 vs. $52.60 \mathrm{~g} / \mathrm{d}$ ). Urea-N excretion was not different between forage levels, but increased linearly with $\mathrm{N}$ intake. Concentration of plasma urea-N was significantly higher for LF and with increasing $\mathrm{N}$ intake. Urea clearance rate $(\mathrm{L} / \mathrm{h})$ did not differ between forage levels and increased, but at a decreasing rate, as $\mathrm{N}$ intake increased. A significant interaction resulted from urea clearance increasing at a greater rate and resulting in higher values for $\mathrm{HF}$, whereas clearance of urea for heifers fed LF resulted in significantly lower maximal values. Like urea- $\mathrm{N}$ excretion, daily urinary $\mathrm{N}$ excretion was affected only by
\end{abstract}

\footnotetext{
Received September 13, 2008.

Accepted December 2, 2008.

${ }^{1}$ This research was a component of NC-1042; Management Systems to Improve the Economic and Environmental Sustainability of Dairy

${ }^{2}$ Corresponding author: ajh@psu.edu
} Enterprises.
$\mathrm{N}$ intake. Retained $\mathrm{N}$ responded linearly to increased levels of $\mathrm{N}$ intake. The significant reduction observed in fecal $\mathrm{N}$ excretion for LF was counterbalanced by numerical increases in urinary $\mathrm{N}$ excretion so that total $\mathrm{N}$ excretion and retention were not different between forage levels. The percentage of $\mathrm{N}$ intake that was retained only tended to be affected by an interaction and was not significantly affected by forage level. It is concluded that increasing $\mathrm{N}$ intake increases the digestibility of $\mathrm{OM}$, the magnitude of which depends on the level of dietary forage provided. Furthermore, differences in $\mathrm{N}$ utilization between $\mathrm{LF}$ and $\mathrm{HF}$ in this trial were small and were not evident until $\mathrm{N}$ intake increased to impractical levels.

Key words: $\mathrm{N}$ balance, limit feeding, dairy heifer, forage:concentrate

\section{INTRODUCTION}

Utilization of dietary nitrogen is very inefficient in growing ruminants compared with growing nonruminant farm animals. Reasons for this observation are varied and include utilization of absorbed AA for gluconeogenesis (Reynolds et al., 1991a), utilization of AA to support gastrointestinal tract (GIT) protein turnover (Attaix et al., 1988) and energy requirements (Lobley et al., 2003), and deamination of dietary AA by the ruminal microflora (Eschenlauer et al., 2002). However, the presence of the ruminal microflora does provide the ruminant with an opportunity to consume NPN to meet some, and potentially all, AA requirements through AA synthesis from $\mathrm{NH}_{3}$ and dietary carbohydrate (Virtanen, 1966); the extent of incorporation of $\mathrm{NH}_{3}$ to microbial AA depending on preformed AA availability (Atasoglu et al., 2004) and the source of carbohydrate (Hristov et al., 2005).

When low-forage $(\mathbf{L F})$ diets are fed to ruminants at energy intakes equal to high-forage (HF) diets, $\mathrm{N}$ retention and efficiency of $\mathrm{N}$ utilization are often improved with the LF diets (Murphy et al., 1994; Driedger and Loerch, 1999; Moody et al., 2007), although the improvements do not attain statistical significance in all cases (Reynolds et al., 1991b; Kirkpatrick et al., 1997; Hill et al., 2007). However, in many of the experiments 
in which forage to concentrate ratios have been altered and $\mathrm{N}$ utilization evaluated, the rations either differed in $\mathrm{N}$ intake $(\mathrm{g} / \mathrm{d}$ ), energy intake (Mcal of $\mathrm{ME} / \mathrm{d}$ ), or both, although altering the levels of $\mathrm{N}$ and energy intake affects the partitioning of $\mathrm{N}$ between retention and excretion in growing cattle (Schroeder and Titgemeyer, 2008; Zanton and Heinrichs, 2008a).

Improved feed efficiency and unaltered growth and first-lactation characteristics have been observed from dairy heifers raised with reduced proportions of dietary forage provided at restricted intakes (Hoffman et al., 2007; Zanton and Heinrichs, 2007). If N efficiency is also improved by reducing the proportions of forage in ruminant diets, then an opportunity may exist to reduce feed costs and the environmental impact associated with raising dairy heifers through reducing the provision of feed protein in an LF, limit-feeding management system. The extent of alterations in $\mathrm{N}$ utilization for limit-fed LF and HF diets across a large range of $\mathrm{N}$ intakes is unavailable. Therefore, the objective of this experiment was to evaluate efficiency of nutrient and $\mathrm{N}$ utilization of dairy heifers fed LF and HF diets at equal ME intakes and 4 levels of $\mathrm{N}$ intake. The hypothesis is that $\mathrm{N}$ will be utilized with improved efficiency when provided as a component of a LF diet compared with a HF diet.

\section{MATERIALS AND METHODS}

\section{Animals, Diets, and Experimental Design}

All procedures involving the use of animals were approved by the Pennsylvania State University Institutional Animal Care and Use Committee. Eight Holstein heifers $(12.3 \pm 0.4 \mathrm{mo}$ and $362 \pm 7 \mathrm{~kg}$ initial age and BW, respectively) were randomly assigned to 2 forage levels: LF (25\% forage) and HF ( $75 \%$ forage) and to an $\mathrm{N}$ intake sequence within forage level administered according to a split-plot, $4 \times 4$ Latin square design with 28-d periods. The whole-plot factor is the proportion of forage in the diet and the subplot is the level of $\mathrm{N}$ intake and all diets were provided at a level calculated to provide equal intakes of ME. The forage components of the diet, corn silage and wheat straw, were chosen to provide minimal levels of $\mathrm{N}$ to the diet to enable a greater range of $\mathrm{N}$ intakes allowable and held constant within forage level to reduce the effect that variation in forage $\mathrm{N}$ concentration would have on the $\mathrm{N}$ intake between forage levels. The levels of $\mathrm{N}$ intake chosen were based on the range of $\mathrm{N}$ intakes observed in the analysis of literature data by Zanton and Heinrichs (2008a) and were formulated to be 1.00 (Low), 1.67 (MLow), 2.33 (MHigh), and 3.00 (High) g of N/kg of $\mathrm{BW}^{0.75}$ per day. Because energy concentration of the formulated rations differed between forage levels, DMI was greater for the HF group and, consequently, the concentration of $\mathrm{N}$ was required to be lower for heifers fed the $\mathrm{HF}$ diet to maintain equal $\mathrm{N}$ intakes between forage levels. Alterations in $\mathrm{N}$ concentration were made by exchanging high protein by-products and urea for starch in both forage levels without changing the forage component of the diet (Table 1). Rations were balanced to maintain a consistent chemical composition across $\mathrm{N}$ intakes (within forage level) and equivalent DMI within forage level.

Heifers were weighed on $\mathrm{d} 0$ and 1,7 and 8,14 and 15 of each period; the amount of feed offered for the following interval being based on the average of the previous 2 weights and provided at a level formulated to allow for $800 \mathrm{~g} / \mathrm{d}$. Rations were mixed daily (Super Data Ranger, American Calan, Northwood, NH) before feeding at $1200 \mathrm{~h}$ by preparing the LF High- and Low-N rations and the HF High- and Low-N rations and by mixing the appropriate proportion of the 2 rations to prepare the intermediate- $\mathrm{N}$ treatment rations. Corn silage DM was evaluated thrice weekly and ration alterations were made as required; the DM concentration of the LF ration was reduced to $65 \%$ (from approximately $75 \%$ ) by the addition of water to minimize dustiness and within-meal sorting. Refusals (if present) and feed samples were collected daily during sample collection periods immediately before feeding. Heifers were housed in a ventilated, environmentally controlled tie-stall barn with rubber mattress bedding. Heifers were allowed access to an exercise lot for $2 \mathrm{~h}$ before feeding on days on which sampling was not occurring. Water was available for ad libitum consumption and the volume of water consumed daily was monitored using unidirectional flow meters (Sensus Metering Systems, Uniontown, PA).

\section{Sample Collection and Analysis}

Adaptation to treatment rations were made over the first $18 \mathrm{~d}$ of each period followed by $10 \mathrm{~d}$ of sampling. Between 0600 and $0800 \mathrm{~h}$ on d 18, heifers were catheterized in the right jugular vein (16-gauge, $13.3 \mathrm{~cm}, \mathrm{BD}$ Angiocath, Franklin Lakes, NJ) and sampled at times relative to feeding of $0,1,2,3,4,5,6,7,8,10,12,16$, 20 , and $24 \mathrm{~h}$. Immediately after sampling, blood was centrifuged at $4,000 \times g$ at $4^{\circ} \mathrm{C}$ for $15 \mathrm{~min}$, and plasma was aspirated and stored at $-20^{\circ} \mathrm{C}$ until analysis for urea N (procedure no. 0580, Stanbio Laboratory Inc., San Antonio, TX).

Feces and urine were completely collected from d 20 immediately after feeding to d 28 immediately before feeding for $8 \mathrm{~d}$ of total collection. Urine was collected through the use of the urine cup collection method of 
Table 1. Ingredient and chemical composition of treatment rations offered containing low (LF) or high (HF) levels of forage and 4 levels of $\mathrm{N}$ intake [1.00 (Low), 1.67 (MLow), 2.33 (MHigh), 3.00 (High) g of N/kg of $\mathrm{BW}^{0.75}$ per d]

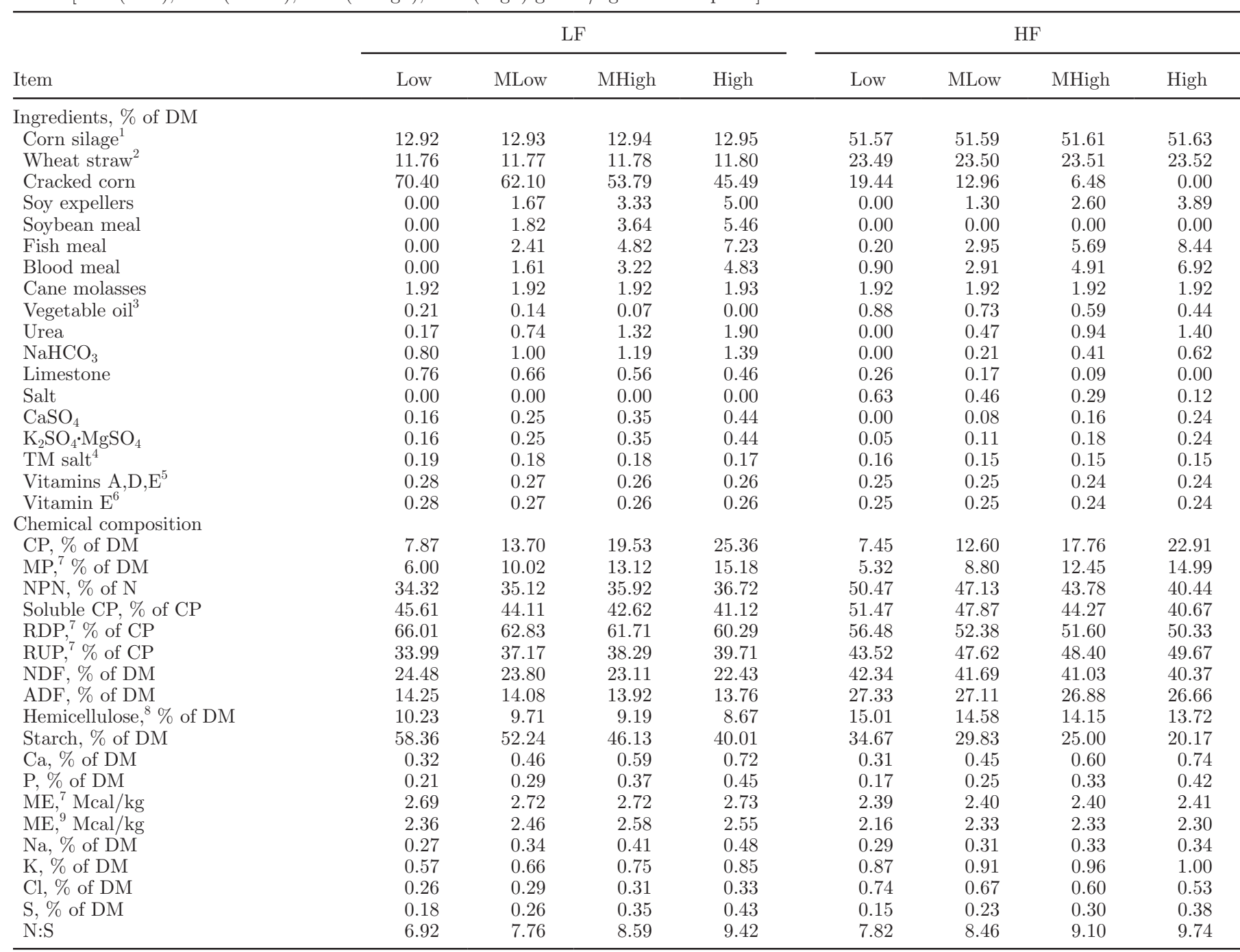

${ }^{1}$ Corn silage contained $7.58 \%$ CP, $39.50 \%$ NDF, $24.80 \%$ ADF, $32.75 \%$ starch.

${ }^{2}$ Wheat straw contained $3.40 \%$ CP, $82.17 \%$ NDF, $56.77 \%$ ADF, $0.67 \%$ starch.

${ }^{3} 50 \%$ corn oil and $50 \%$ soybean oil

${ }^{4}$ Trace mineralized salt contained Na, 33.81\%; Cl, 52.13\%; Co, 70 mg/kg; Cu, 400 mg/kg; I, 70 mg/kg; Fe, 1,750 mg/kg; Mn, 2,800 mg/kg; Zn, $3,500 \mathrm{mg} / \mathrm{kg}$.

${ }^{5}$ Vitamins A, D, E contained 4,000 kIU of vitamin A/kg; 1,000 kIU of vitamin D/kg; 4,000 IU of vitamin E/kg

${ }^{6}$ Vitamin E contained 20,000 IU of vitamin E/kg.

${ }^{7} \mathrm{MP}$, RDP, RUP, and ME were calculated according to NRC (2001) using observed BW, DMI, and ingredient composition.

${ }^{8}$ Hemicellulose $=\mathrm{NDF}-\mathrm{ADF}$

${ }^{9} \mathrm{ME}$ : calculated as digestible $\mathrm{OM} \times 0.82 \times 4.409 / \mathrm{DMI}$.

Fellner et al. (1988) modified to enable floor-level urine collection and attachment without gluing the cups to the heifer. Urine was weighed and subsampled daily after feeding. Urine $\mathrm{pH}$ was monitored and acidified to $\mathrm{pH}<2$ by the addition of $12 \mathrm{~N} \mathrm{HCl}$ as required; realized equivalents of $\mathrm{H}^{+}$added were 1.30, 1.36, 1.52, and 1.61 for Low to High $\mathrm{N}$ intake levels, respectively (SE \pm 0.08 ; forage effect $P>0.35$ ). These levels of acidification would be sufficient to capture at least $10 \%$ of digested $\mathrm{N}$ (assuming no $\mathrm{N}$ retention), wherein $\mathrm{NH}_{3}$ typically comprises $<10 \%$ of urine $\mathrm{N}$ (Szanyiova et al., 1995). Feces were collected as deposited into covered containers, which were weighed and subsampled daily after feeding. On 2 d per period feces and unacidified, chilled $\left(4^{\circ} \mathrm{C}\right)$ urine were subsampled from 4 heifers (1 observation per heifer per period) and ammonia vola- 
tilization was analyzed using a bench-top, steady-state (dynamic) flux chamber under laboratory conditions as detailed by Lascano et al. (2008).

Feed ingredients (dry basis) and feces (wet basis) were composited by period. Samples were dried in a forced-air oven at $55^{\circ} \mathrm{C}$ for $48 \mathrm{~h}$, ground through a 1-mm screen (Wiley mill, Arthur Thomas, Philadelphia, PA), and analyzed for analytical DM by drying a $102^{\circ} \mathrm{C}$ for $48 \mathrm{~h}$ and ash by combustion at $600^{\circ} \mathrm{C}$ for $6 \mathrm{~h}$ (AOAC, 1990), NDF (with the inclusion of $\alpha$-amylase and sodium sulfite), and ADF (Van Soest et al., 1991). Starch was analyzed on samples reground to pass through a $0.5-\mathrm{mm}$ screen by a modification of the procedure reported by Bach Knudsen (1997; modification included $150 \mathrm{mg}$ of sample, 45 units of amyloglucosidase, and analysis of released glucose monomers with procedure no. 1075, Stanbio Laboratory Inc.). Feed N was analyzed on dried samples, and fecal and urine $\mathrm{N}$ were analyzed on wet samples by the Kjeldahl method (AOAC, 1990). Urine was also analyzed for urea N (procedure no. 0580; Stanbio Laboratory Inc.) and creatinine (procedure no. 0400; Stanbio Laboratory Inc.). Fractionation of feed and fecal $\mathrm{N}$ was determined on dried samples as NPN [TCA method, feed only], ADIN, and neutral detergent insoluble $\mathrm{N}$ by the procedures of Licitra et al. (1996). Metabolizable energy intake was calculated for each heifer within each period using the observed digestible $\mathrm{OM}$ intake $\times 4.409 \times 0.82(\mathrm{NRC}, 2001)$ assuming digestible $\mathrm{OM}$ intake and total digestible nutrient intake are equal.

\section{Statistical Analysis}

Data were analyzed as a split-plot, Latin square design with fixed effects of period, forage, $\mathrm{N}$ intake level, and forage $\times \mathrm{N}$ intake interaction and a random effect of heifer(forage). Adaptation to treatment lasted $18 \mathrm{~d}$ based on the results of Biddle et al. (1975) in which stabilization of urine $\mathrm{N}$ excretion occurred at approximately $3 \mathrm{wk}$ of consuming an $\mathrm{N}$ depletion ration; responses during repletion were less consistent. Given this consideration, $\mathrm{N}$ level treatment sequences were balanced for carryover with respect to previous $\mathrm{N}$ level such that all treatments followed every other treatment once; therefore, the fixed effect of previous treatment was included in the statistical analysis. For responses in which multiple observations occur within a period the fixed effect of time and fixed effect interactions with time were included in the statistical analysis. Correlation between residuals was modeled using the first-order autoregressive covariance structure when multiple observations were made over time within heifer within period. The effect of forage was evaluated with the denominator degrees of freedom and the error term as- sociated with whole plot error of heifer(forage), and the effect of $\mathrm{N}$ intake and the interaction evaluated against the pooled residual error. Variance homogeneity was evaluated for the main effects of forage and $\mathrm{N}$ intake and time relative to feeding when repeated measures were analyzed; evidence of significant heterogeneity was determined using a Levene test for equality of variance. Normality of the residuals was evaluated by using the Shapiro-Wilk test for normality. Differential responses between forage levels to $\mathrm{N}$ intake were assessed for some variables through mixed model regression analysis; output from this analysis is displayed in figures as the adjusted (for random effect of heifer) response against $\mathrm{N}$ intake. Least squares means are presented in tables and evidence for statistical significance was declared at $P<0.05$.

\section{RESULTS AND DISCUSSION}

\section{Dietary Intakes}

Actual intakes of $\mathrm{N}\left(\mathrm{g} / \mathrm{kg}\right.$ of $\mathrm{BW}^{0.75}$, Table 2) were lower than the formulated levels because of a greater rate of gain than anticipated for all groups, lower levels of $\mathrm{N}$ analyzed in period composited samples than in pretrial samples used for formulation, and the presence of refusals for some heifers fed the HF diet. However, the differences in formulated intakes and observed $\mathrm{N}$ intakes do little to change the interpretation of the data because the profile of $\mathrm{N}$ intake increased linearly and the maximum difference in $\mathrm{N}$ intake between forage level and within $\mathrm{N}$ intake level was $0.02 \mathrm{~g}$ of $\mathrm{N} / \mathrm{kg}$ of $\mathrm{BW}^{0.75}$.

Intake of other nutrients and chemical components were also affected by the alterations in the $\mathrm{N}$ composition of the ration (Table 2); the primary differences were observed for $\mathrm{OM}$ and starch intake varying negatively with increasing $\mathrm{N}$ intake, ash intake varying positively, and ME intake varying positively and quadratically with $\mathrm{N}$ intake. Importantly, NDF intake was not affected by $\mathrm{N}$ intake, and $\mathrm{ME}$ and $\mathrm{CP}$ intake were not different between forage levels $(P>0.10)$. Sources of dietary N were different for different levels of forage and $\mathrm{N}$ intake, which will be the case for natural diets. These differences in $\mathrm{N}$ source are likely realized through the differences observed in calculated MP intakes. The extent to which differences or lack of differences observed in this experiment are due to differences in sources of $\mathrm{N}$ or MP intake are not completely distinguishable from other differences in the main factors altered in this experiment. Regression analysis of the responses against MP intake (results not shown) does not, however, result in a different interpretation than that reached by analysis of the independent variables experimentally manipulated. 
Table 2. Daily feed component and water intake by heifers fed low (LF) or high forage (HF) diets at 4 levels of $\mathrm{N}$ intake [1.00 (Low), 1.67 (MLow), 2.33 (MHigh), 3.00 (High) g of N/kg of $\mathrm{BW}^{0.75}$ per d]

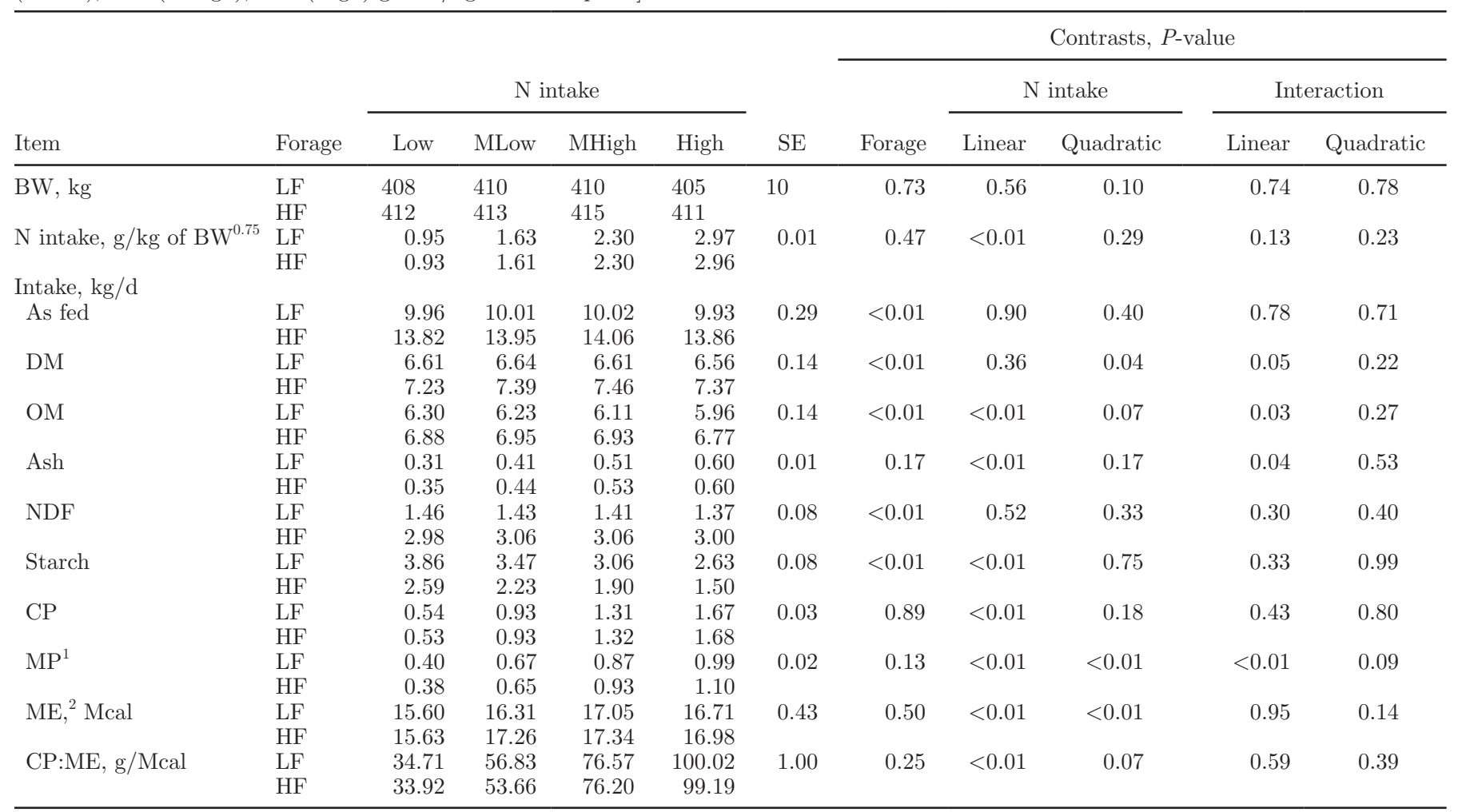

${ }^{1} \mathrm{MP}$ calculated according to NRC (2001) using observed BW, DMI, and ingredient composition.

${ }^{2} \mathrm{ME}$ calculated as digestible $\mathrm{OM} \times 0.82 \times 4.409$.

Increased intake in $\mathrm{CP}$ requires another macronutrient intake to be reduced for isoenergetic conditions to prevail. The typical choice for this replacement in ruminant and nonruminant nutritional experiments is starch, as was the case in this experiment. The principal difference between this experiment and others is that, because there were 2 levels of NDF fed, starch intake changed linearly over a considerably greater range $(2.36$ $\mathrm{kg})$ than either CP $(1.15 \mathrm{~kg})$ or NDF $(1.65 \mathrm{~kg})$. The sum total of these alterations is that heifers were fed diets containing 2 levels of NDF, 4 levels of linearly increasing CP intake, and 7 levels of linearly decreasing starch intake. Inferences will focus on forage level and $\mathrm{CP}$ intake, but pertinent relationships (or lack thereof) with starch will also be highlighted when relevant.

\section{Diet Digestibility}

Digestibility of dietary components is shown in Table 3. Dry matter and OM digestibility were improved by reducing the forage component of the diet and increasing intake of N. Comparable observations have been made previously with beef cattle (Reynolds et al., 1991b), sheep (Murphy et al., 1994), dairy heifers
(Moody et al., 2007; Hill et al., 2007), and dry dairy cows (Driedger and Loerch, 1999) when LF diets are compared with HF diets at restricted intakes. Likewise, increasing dietary $\mathrm{N}$ intake for dairy heifers has been shown in several experiments to enhance the digestibility of DM and OM (Hoffman et al., 2001; Marini and Van Amburgh, 2005). As observed in Figure 1, the relationship between the response to additional $\mathrm{N}$ intake depended on the forage level, in that the level of improvement in apparent OM digestibility was greater for LF than for HF. The response in OM digestibility to additional $\mathrm{N}$ intake was also maximized at different levels of dietary CP concentration (18.43 vs. 13.90 for LF and HF, respectively). This relationship indicates that dietary $\mathrm{CP}$ concentration limited apparent $\mathrm{OM}$ digestibility over a greater range for $\mathrm{LF}$ than for $\mathrm{HF}$ and that after the limitation had been removed, apparent OM digestibility was limited by the chemical composition of the OM.

Digestibility of NDF increased in a manner consistent with OM with increasing $\mathrm{N}$ intake; however, the significant reduction in NDF digestibility for the LF diet was primarily due to significant reductions in hemicellulose digestibility because digestibility of ADF did not differ 
Table 3. Nutrient digestibility by heifers fed low (LF) or high forage (HF) diets at 4 levels of N intake [1.00 (Low), 1.67 (MLow), 2.33 (MHigh), 3.00 (High) $\mathrm{g}$ of $\mathrm{N} / \mathrm{kg}$ of $\mathrm{BW}^{0.75}$ per d]

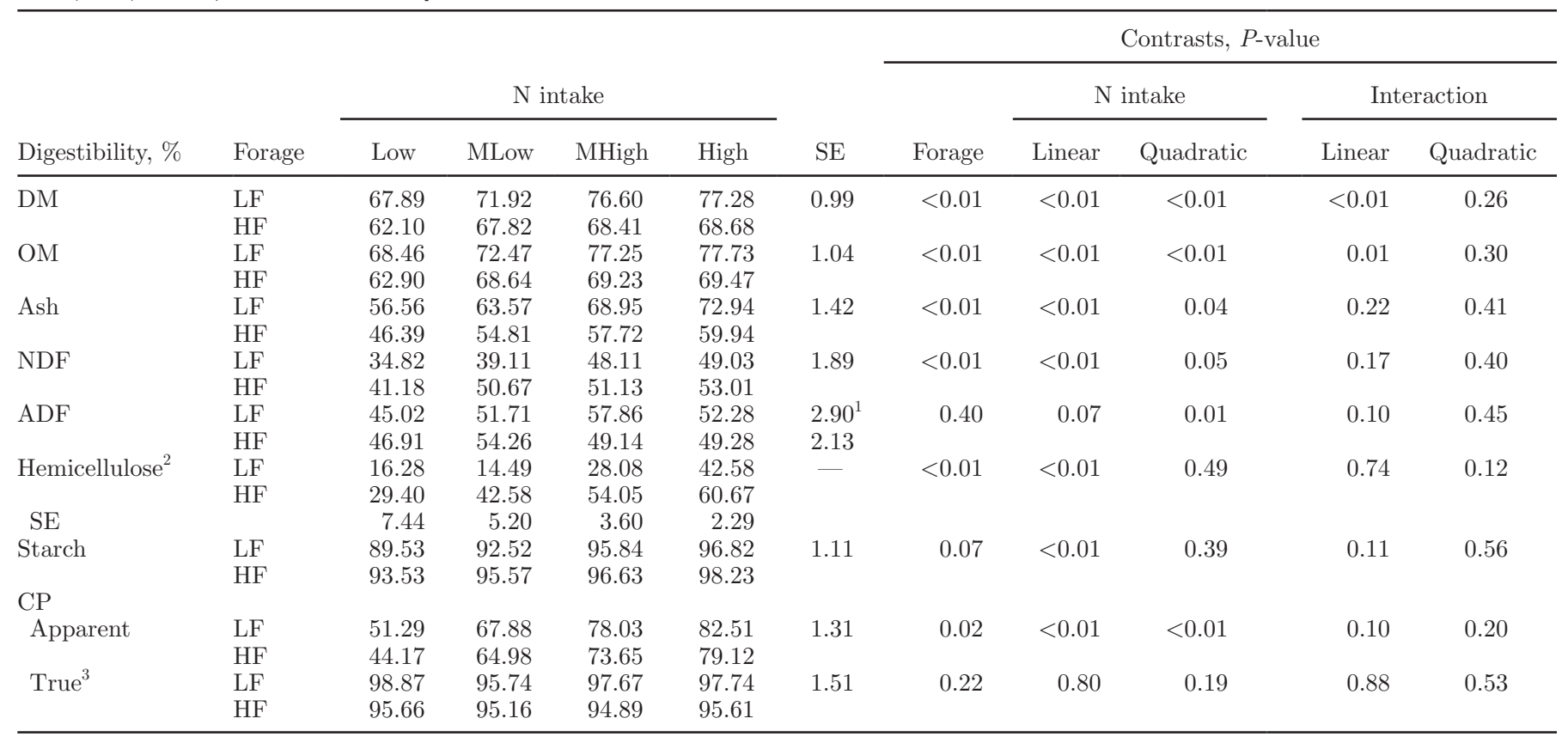

${ }^{1}$ Variance heterogeneity was observed across forage or $\mathrm{N}$ intake levels for indicated items.

${ }^{2}$ Hemicellulose $=$ NDF - ADF .

${ }^{3}$ True $\mathrm{CP}$ digestibility is predicted as $[\mathrm{N}$ intake $-($ fecal $\mathrm{N}-6.217 \times \mathrm{DMI})] / \mathrm{N}$ intake based on the results of linear regression analysis.

between forage levels. Significant linear and quadratic trends for increased NDF digestibility with increasing $\mathrm{N}$ intake resulted from the combination of increased linear digestibility of hemicellulose and quadratic effects to increased $\mathrm{N}$ intake on the digestibility of ADF. The reduction in NDF digestibility was consistent with the results reported by Moody et al. (2007) and Kirkpatrick et al. (1997) as well as that which would be expected based on the anticipated reduction in rumen $\mathrm{pH}$ associated with the consumption of the LF diet, although the presence and extent of $\mathrm{pH}$ alterations is unknown for the current experiment. The results for NDF digestibility for the current experiment conflict with the results of several other reports (Colucci et al., 1989; Reynolds et al., 1991b; Murphy et al., 1994) in which lower forage diets resulted in significantly higher NDF digestibility when fed at restricted intakes, likely because of enhanced retention times and more digestible sources of NDF offsetting the negative consequences of reduced ruminal $\mathrm{pH}$. Digestibility of ADF in the current experiment corresponds to neither of these results in that there were no differences between forage levels. The extent to which the level of intake and forages fed affect the differences in responses observed between the different experiments cannot be evaluated from available data, although in the current experiment the ADF from the most indigestible feedstuff offered (wheat straw) comprised a similar proportion of the ADF across all diets ( $48 \%$ of $\mathrm{ADF}$ for $\mathrm{LF}$ vs. $49 \%$ of $\mathrm{ADF}$ for $\mathrm{HF}$ ), which may blunt the impact of the potential improvements in ruminal retention time and highly digestible ADF sources for LF rations.

Starch digestibility was improved as the level of N intake increased for both LF and HF rations. Starch digestibility also tended to be higher for the HF ration. Veira et al. (1980) determined that a linear increase in starch digestibility was associated with increased $\mathrm{N}$ intake, although these results have not been confirmed in subsequent experiments where $\mathrm{N}$ was fed (Streeter and Mathis, 1995) or infused abomasally (Richards et al., 2002). The extent that alterations observed in total-tract starch digestibility are due to ruminal or postruminal digestibility changes is unknown from the current experiment. It has been observed previously that increasing rates of dry matter degradation were observed in situ when rumen $\mathrm{NH}_{3}-\mathrm{N}$ concentration was increased to 6.1 or $12.5 \mathrm{mg} / \mathrm{dL}$ for barley or corn, respectively; increases beyond these levels did not result in significant increases in degradation rate (Odle and Schaefer, 1987). Several experiments with lactating dairy cows, in which rumen $\mathrm{NH}_{3}-\mathrm{N}$ concentration was unlikely to be limiting to rumen starch digestion, have demonstrated that greater intake of starch resulted in greater levels of rumen starch digestibility 


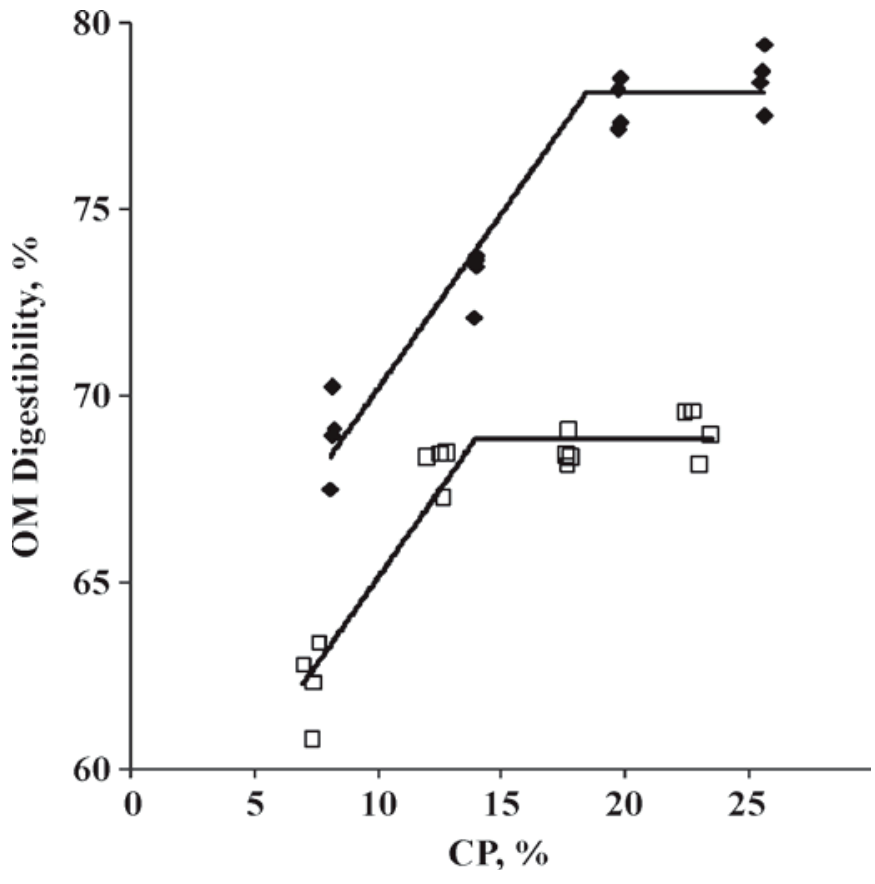

Figure 1. Piecewise regression analysis of the response in OM digestibility to altered levels of dietary $\mathrm{CP}$ concentration for heifers fed low forage $(\mathrm{LF}, \bullet)$ or high forage $(\mathrm{HF}, \square)$ treatment rations at 4 levels of $\mathrm{CP}$ intake. Response functions were significantly different for the different forage levels, but the slope component did not differ $(P$ $>0.297$ ) between the forage levels and was fixed at a constant value for both forage levels. Response for LF is OM digestibility $=60.73+$ $0.94 \times \% \mathrm{CP}$ when $\% \mathrm{CP}<18.43$; when $\% \mathrm{CP}>18.43$, OM digestibility $=78.01$. Response for $\mathrm{HF}$ is $\mathrm{OM}$ digestibility $=55.69+0.94 \times \% \mathrm{CP}$ when $\% \mathrm{CP}<13.90$; when $\% \mathrm{CP}>13.90$, OM digestibility $=68.78$.

and lower levels of postruminal starch digestibility, the reverse occurring with lower starch intake, although total-tract starch digestibility was unaffected in both experiments (Cameron et al., 1991; Ipharraguerre et al., 2005). When casein and starch were infused into the rumen or abomasum of steers according to a factorial experiment, starch infused into the rumen was highly digested in the total tract and unaffected by the site of casein infusion although when starch was infused into the abomasum, total-tract digestibility was lower when infused into the rumen and higher when casein was co-infused into the abomasum (Taniguchi et al., 1995). The trend toward lower starch digestibility for heifers fed LF and improvements realized with increasing $\mathrm{N}$ intake are consistent with the observations of Taniguchi et al. (1995).

Reduced digestibility of starch observed for LF has not been observed in other experiments in which forage level was altered in limit-fed sheep (Colucci et al., 1989; Murphy et al., 1994) or cattle (Colucci et al., 1989). Considering that starch intake increased linearly over a combination of forage and $\mathrm{N}$ intake levels (Table
2 ), the relationship between starch intake and digested starch could be evaluated by regression analysis in the current experiment. Using mixed model regression, a significant quadratic response was observed between starch intake $(\mathrm{x})$ and starch digested in the total tract $(\mathrm{y}): \mathrm{y}=1.054( \pm 0.016 ; P<0.01) \mathrm{x}-0.046( \pm 0.008 ; P$ $<0.01) \mathrm{x}^{2}$ with the intercept not differing from $0(P>$ $0.10)$; responses were not affected by forage level. This response would indicate a continuously increasing, but at a decreasing rate, digestion of dietary starch. Although the quadratic coefficient was highly significant, the absolute reduction in rate of increase in digested starch with increasing starch intake was very minimal in the range of intake observed in the current experiment $(1.50-3.86 \mathrm{~kg} / \mathrm{d})$. From the foregoing discussion it can be inferred that starch intake is more closely related to its disappearance in the total tract than $\mathrm{N}$ intake or forage level individually.

Finally, it can be concluded that digestibility of the major carbohydrate components of the diets (NDF and starch) were individually greater for the HF diets. Because the more highly digestible component (starch) comprises a greater proportion of carbohydrate for the LF ration, the greater OM digestibility for the LF diet is due to the composition of the diet. Enhanced digestibility of OM was not due to a greater level of digestive efficiency for the heifers fed the LF diet because this was reduced for both carbohydrate fractions.

\section{Environmental Excretion}

Consistent with improvements observed in dietary digestibility, fecal wet and dry matter and fecal water excretion are significantly greater for heifers fed HF; also fecal DM and water excretion decreased with increasing $\mathrm{N}$ intake (Table 4). In the current experiment, heifers fed LF produced an average of $60 \%$ of the mass of wet feces as produced by heifers fed HF. Although the magnitude of the changes in wet fecal output differs between experiments as a result of the composition of the diet fed, results of previous research support these observations for limit-fed cattle (Driedger and Loerch, 1999; Hill et al., 2007; Moody et al., 2007). Decreases in wet fecal output do not carry through to decreases in manure output because of numerically greater levels of urine output for heifers fed LF. Urine output was also significantly greater for heifers fed increasing levels of $\mathrm{N}$ as has been observed previously (Bannink et al., 1999; Kume et al., 2008) and greatly contributed to the increasing excretion of total manure observed as $\mathrm{N}$ intake increased. Urine output has also been observed to be increased by the provision of LF diets to dairy heifers (Hill et al., 2007). However, the numerical increase observed in the current experiment was much lower than 
Table 4. Environmental output from heifers fed low (LF) or high forage (HF) diets at 4 levels of N intake [1.00 (Low), 1.67 (MLow), 2.33 (MHigh), 3.00 (High) g of N/kg of $\mathrm{BW}^{0.75}$ per d]

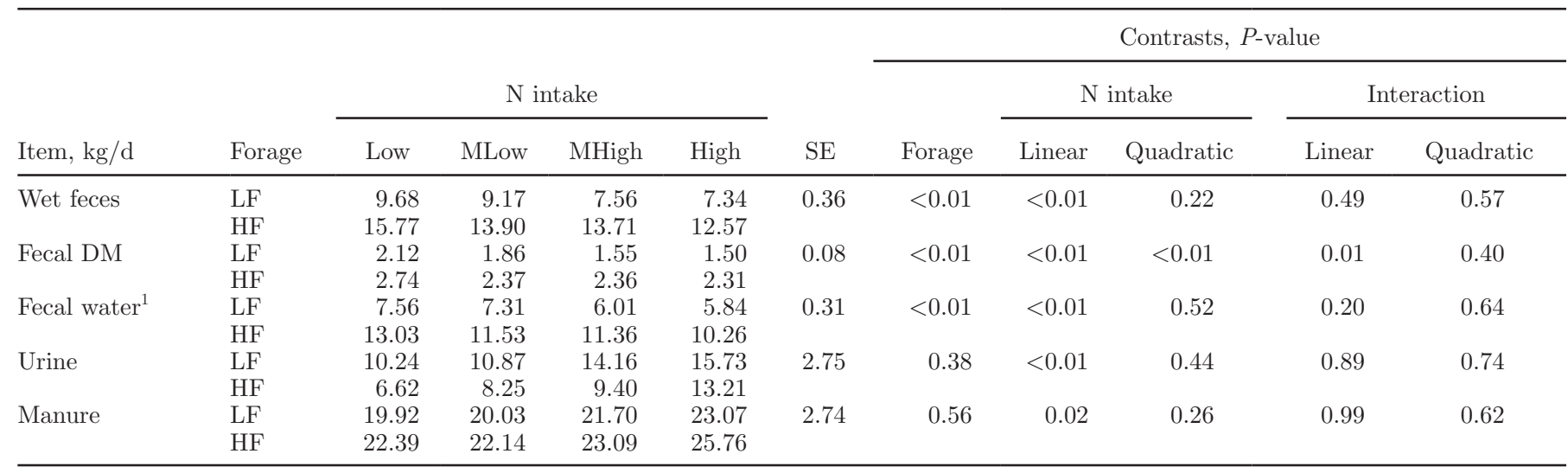

${ }^{1}$ Weight lost on drying at $55^{\circ} \mathrm{C}$.

the increases observed in that experiment but higher than others in which no increases were observed with limit-fed heifers (Moody et al., 2007; Zanton and Heinrichs, 2008b).

The inverse relationship between fecal water excretion and urine excretion in response to alterations of $\mathrm{N}$ intake as well as to forage level is shown in Table 4 , and the distribution relative to water consumption is detailed in Table 5 . Fecal water excretion $(\mathrm{kg})$ was determined to be most highly correlated $(\mathrm{r}=0.989)$ to fecal NDF excretion (kg) among the fecal excretion variables evaluated. The relationship between fecal water excretion (y) and fecal NDF (x) was not differentially affected by level of forage $(P>0.50)$ and could be represented with a common equation as $\mathrm{y}=$ $1.28( \pm 0.45 ; P<0.01)+6.69( \pm 0.43 ; P<0.01) \mathrm{x}$. Water intake was not different between forage levels, regardless of means of expression, whereas water intake increased with greater levels of $\mathrm{N}$ intake. The proportion of water intake that was excreted did not depend upon any of the dietary factors altered and averaged $75.21 \%$, whereas the proportion of intake excreted in feces and urine was affected by both forage level and $\mathrm{N}$ intake. These observations reflect the well-coordinated balance of water through alterations in excreta water output and voluntary water intake, but the strong relationship between NDF excretion and fecal water excretion indicates the importance of the water-holding capacity of undigested fiber or an enhanced rate of passage through the lower GIT in affecting the regulation of partitioning of consumed water. Overall, the responses observed for water partitioning contribute substantially to the lack of significant differences observed in total manure output and limit the effects of improved dietary digestibility observed for LF and with increased $\mathrm{N}$ intake.

\section{Fecal $\mathbf{N}$ and $\mathbf{N}$ Digestibility}

Apparent digestibility of $\mathrm{N}$ increased with increasing $\mathrm{N}$ intake and for heifers fed the LF diet (Table 3). Considering that a significant proportion of fecal $\mathrm{N}$ excreted does not directly originate from the diet (Mason, 1969), true digestibility of dietary $\mathrm{N}$ and nondietary fecal $\mathrm{N}$ (NDFN) was evaluated by regression analysis (Figure 2 ). Response of apparently digested $\mathrm{N}$ ( $\mathrm{y} ; \mathrm{g} / \mathrm{kg}$ of DMI) to $\mathrm{N}$ intake (x; g/kg of DMI) was not different between LF and HF diets $(P>0.35)$ and can be represented by the common equation $\mathrm{y}=-6.217( \pm 0.217)+0.970$ $( \pm 0.008) \mathrm{x}$. Results indicate that, when expressed relative to DMI, no dietary differences in NDFN and true digestibility exist between HF and LF limit-fed heifers (Table 3). Fecal $\mathrm{N}$ was also partitioned using neutral and acid detergent solutions (Table 6; Mason, 1969). Insoluble $\mathrm{N}$ (presumably of feed origin) was higher in feces for heifers fed HF diets and with increasing intake of $\mathrm{N}$ when determined using either acid or neutral detergent solutions. Detergent soluble $\mathrm{N}$ was not different between forage levels for both detergent solutions, but increased as $\mathrm{N}$ intake increased-although this response was strongest for heifers fed the HF diet and determined using neutral detergent. Whereas results from the regression analysis extrapolate a single level of NDFN for all $\mathrm{N}$ intakes within forage level, analysis with detergents can yield individual NDFN for all diets. When related to DMI and extracted with neutral detergent, excretion of NDFN increased with increasing $\mathrm{N}$ intake and at a greater rate for heifers fed the HF ration, although differences between forage levels were not significant. Excretion of NDFN extracted with acid detergent $(\mathrm{g} / \mathrm{kg}$ of DMI) was unaffected by dietary treatment. Regardless of extraction solution, the proportion of fecal $\mathrm{N}$ that was NDFN was greater when 
Table 5. Water intake and distribution in excreta from heifers fed low (LF) or high forage (HF) diets at 4 levels of $\mathrm{N}$ intake [1.00 (Low), 1.67 (MLow), 2.33 (MHigh), 3.00 (High) g of $\mathrm{N} / \mathrm{kg}$ of $\mathrm{BW}^{0.75}$ per d]

\begin{tabular}{|c|c|c|c|c|c|c|c|c|c|c|c|}
\hline \multirow{2}{*}{ Item } & \multirow{2}{*}{ Forage } & & & & & \multirow{2}{*}{$\mathrm{SE}$} & \multicolumn{5}{|c|}{ Contrasts, $P$-value } \\
\hline & & \multicolumn{4}{|c|}{$\mathrm{N}$ intake } & & Forage & \multicolumn{2}{|c|}{$\mathrm{N}$ intake } & \multicolumn{2}{|c|}{ Interaction } \\
\hline \multicolumn{12}{|l|}{ Water intake, $\mathrm{L} / \mathrm{d}$} \\
\hline \multirow[t]{2}{*}{ Voluntary } & $\mathrm{LF}$ & 19.42 & 20.63 & 22.68 & 26.24 & 3.01 & 0.79 & $<0.01$ & 0.23 & 0.20 & 0.74 \\
\hline & $\mathrm{HF}$ & 19.34 & 20.24 & 21.32 & 23.62 & & & & & & \\
\hline \multirow[t]{3}{*}{ Total, /kg of DMI } & $\mathrm{LF}$ & 3.48 & 3.60 & 4.00 & 4.53 & 0.46 & 0.83 & $<0.01$ & 0.14 & 0.09 & 0.91 \\
\hline & $\mathrm{HF}$ & 3.59 & 3.62 & 3.73 & 4.12 & & & & & & \\
\hline & $\mathrm{LF}$ & 42.53 & 25.59 & 20.73 & 17.35 & 3.75 & 0.55 & $<0.01$ & $<0.01$ & 0.16 & 0.68 \\
\hline Total, / $\mathrm{kg}$ of $\mathrm{CP}$ intake & $\mathrm{HF}$ & 49.14 & 28.96 & 21.57 & 17.65 & & & & & & \\
\hline \multicolumn{12}{|c|}{ Water excreted per consumed, $\%^{2}$} \\
\hline \multirow[t]{2}{*}{ Feces } & $\mathrm{LF}$ & 35.95 & 33.46 & 24.19 & 20.57 & 3.81 & 0.02 & $<0.01$ & 0.93 & 0.74 & 0.79 \\
\hline & $\mathrm{HF}$ & 50.40 & 43.74 & 40.65 & 34.56 & & & & & & \\
\hline
\end{tabular}

${ }^{1}$ Total water intake $=$ voluntary water intake + feed water.

${ }^{2}$ Consumption is total water intake and excretion includes fecal water calculated as weight lost on drying at $55^{\circ} \mathrm{C}$ and total weight of urine output.

the LF diet was fed, a result explained by the lower excretion of dietary $\mathrm{N}$ for heifers fed these diets. As a result of this observation, true $\mathrm{N}$ digestibility was determined to be greater for heifers fed LF and increased significantly with increasing levels of $\mathrm{N}$ intake.

The discrepancies observed in the current experiment between detergent solutions have also been observed by Mason (1969) when describing the technique, although the divergence of values determined in this experiment was greater than that observed in the earlier experiment. Explanations may relate to the inability of neutral detergent solution to completely extract the mucopeptide fraction of the bacterial cell wall, alterations occurring during the storage of feces being more evident in the neutral detergent extraction, the analysis of dried feces in the current experiment compared with fresh feces, or a combination of the previous explanations or an as yet unidentified factor (Mason, 1969). Although the regression equations or regression coefficients were not significantly different between forage levels (Figure 2), results of acid detergent extraction agree most closely with the results determined for the regression analysis of apparently digested $\mathrm{N}$ (evaluated with fecal N excretion determined on fresh feces) against $\mathrm{N}$ intake when the results of the equations are considered separately. As such, when evaluated with acid detergent, NDFN averaged $6.34 \mathrm{~g} / \mathrm{kg}$ of DMI and true digestibility averaged $97.58 \%$ for heifers fed the LF diet compared with $6.217 \mathrm{~g} / \mathrm{kg}$ of DMI and $97.0 \%$ determined by regression analysis and heifers fed the HF diet with NDFN of 6.09 $\mathrm{g} / \mathrm{kg}$ of DMI and $95.24 \%$ determined with acid detergent compared with $6.105 \mathrm{~g} / \mathrm{kg}$ of DMI and $95.82 \%$ determined by regression analysis.

Previous experiments have observed that when starch (Orskov et al., 1970) or glucose (Thornton et al., 1970) was infused postruminally there was greater excretion of fecal $\mathrm{N}$ than when no fermentable carbohydrate was infused. In the current experiment, no relationship between starch intake, starch digested in the total tract, or fecal starch excretion and NDFN could be identified. There was also no relationship between NDFN excretion $(\mathrm{g} / \mathrm{kg}$ of DMI) and forage level (thus, NDF intake; Figure 2), in agreement with the results obtained by Ouellet et al. (2002) using ${ }^{15} \mathrm{~N}$ dilution. There was also no change in NDFN excretion with changing $\mathrm{N}$ intake when analyzed with acid detergent, which conflicts with results from several other sources wherein NDFN excretion increases as $\mathrm{N}$ intake increases where the specific endogenous $\mathrm{N}$ losses increase (Stein et al., 2007); the complexity of the $\mathrm{N}$ dynamics in the ruminant GIT is a likely explanation for this difference because the former results were derived from primarily nonruminant experiments. Thus, from the results of this experiment, NDFN losses were not different between forage levels and comprised a large proportion of fecal N. Also, the true $\mathrm{N}$ digestibility was greater for the LF diets than the HF diets because of greater levels of dietary $\mathrm{N}$ excreted in the feces for HF.

The combination of unaltered NDFN and increased levels of dietary $\mathrm{N}$ excretion into the feces resulted in 


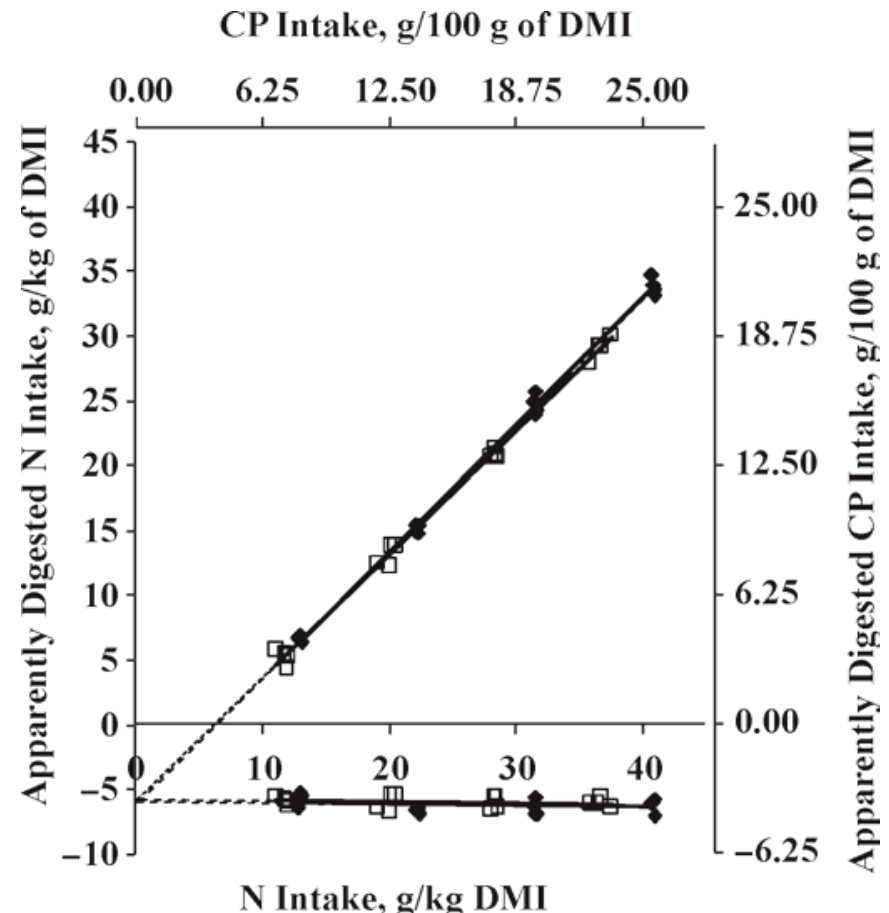

Figure 2. Relationship between dietary $\mathrm{N}$ intake ( $\mathrm{g} / \mathrm{kg}$ of $\mathrm{DMI})$ and $\mathrm{N}$ that was apparently digested for heifers fed low forage (LF, or high forage (HF, $\square$ ) treatment rations at 4 levels of $\mathrm{CP}$ after adjustment for random heifer effects. Extrapolations are indicated by broken lines. Parenthetical values associated with the equation are standard errors. Lines are not significantly different $(P>0.20)$ and individual coefficients are not different $(P>0.20)$ and a common equation representing both forage levels is: Apparently digested $\mathrm{N}=-6.217$ $( \pm 0.217)+0.970( \pm 0.008) \times \mathrm{N}$ intake. Individual equations are, for LF: Apparently digested $\mathrm{N}=-6.306( \pm 0.312)+0.980( \pm 0.010) \times \mathrm{N}$ intake, and for HF: Apparently digested $\mathrm{N}=-6.105( \pm 0.312)+0.958$ $( \pm 0.011) \times \mathrm{N}$ intake. Nondietary fecal $\mathrm{N}$ is represented by negative values to correspond with nondietary fecal $\mathrm{N}$ determined by extrapolation and determined using acid detergent soluble N. The common equation of NDFN $=-5.843( \pm 0.291 ; P<0.01)-0.011( \pm 0.011 ; P$ $>0.33) \times \mathrm{N}$ intake; lines were not different between forage groups $(P$ $>0.76)$.

significantly greater levels of fecal $\mathrm{N}$ excretion for heifers fed HF compared with LF at all levels of $\mathrm{N}$ intake (Table 7). Increasing $\mathrm{N}$ intake resulted in significant increases in fecal $\mathrm{N}$ excretion, with the greatest increases occurring for $\mathrm{HF}$ because of the greater excretion of feed $\mathrm{N}$, as discussed previously. These numerical differences between LF and HF were, for the most part, maintained in the $\mathrm{N}$ that was apparently digested, although the differences were not significant $(P>0.23)$.

\section{Plasma Urea, Urine Components, and Renal Responses}

Urine $\mathrm{N}$ increased linearly as $\mathrm{N}$ intake increased and was not significantly different between forage levels (Table 7). As would be expected based on several experiments (Hoffman et al., 2001; Gabler and Heinrichs,
2003; Marini and Van Amburgh, 2003), plasma urea-N (PUN) levels increased significantly and linearly as N intake increased (Table 8), although the postprandial concentration profiles are similar for all levels of $\mathrm{N}$ intake and forage level (Figure 3). Levels of PUN were also significantly greater for heifers fed LF despite the constant intake of $\mathrm{N}$ and lower levels of soluble protein intake. Because PUN concentration represents the balance between entrance and removal of urea-N, assuming a constant plasma volume, forage level-dependent alterations in these fluxes likely occurred independent of $\mathrm{N}$ intake. Several sources have observed that as the level of forage in the diet increases, the absorption of $\mathrm{NH}_{3}$ and therefore, the PUN concentration and net hepatic urea flux increase (Huntington, 1989; Reynolds et al., 1991a; Seal et al., 1992). However, caution must be exercised when ascribing the results of the aforementioned experiments to the proportion of forage in the diet, because, in each case, $\mathrm{N}$ intake was greater for the animals fed HF. When $\mathrm{N}$ intake is similar (Lobley et al., 1996) or equal (Huntington et al., 1996), $\mathrm{NH}_{3}$ absorption is unaffected by forage level of the diet in contrast to the previous experiments in which forage level and $\mathrm{N}$ intake were altered simultaneously. Results of this latter experiment did, however, show greater plasma urea concentrations as well as higher liver urea flux for animals fed higher concentrate, lower forage diets despite equivalent liver $\mathrm{NH}_{3}$ and $\alpha$-amino $\mathrm{N}$ net fluxes (Huntington et al., 1996).

Plasma urea has 2 sites of exit from the body: recycled to the GIT and excretion in urine. Sunny et al. (2007) concluded that the transfer of PUN to the GIT was limited by the capture of the urea within the GIT and not by transport/diffusion into the GIT. Transfer of urea to the rumen has been increased by infusion of sucrose ruminally (Kennedy, 1980), and the inclusion of rapidly fermentable carbohydrates in the diet (Norton et al., 1982; Lobley et al., 2000). Greater transfer of urea to the GIT was also observed through greater provision of dietary N in sheep (Cocimano and Leng, 1967; Bunting et al., 1987; Marini et al., 2004) and cattle (Bunting et al., 1989) in spite of the reduced urease activity of bacteria adherent to the surface of various sections of the GIT (Marini et al., 2004). Few experiments exist, however, in which urea-N recycling to the GIT is examined with animals receiving different forage levels but with isonitrogenous and isoenergetic intakes. The results of several available experiments indicate that recycling of urea $\mathrm{N}$ to the rumen is greater for animals fed LF diets (Norton et al., 1982; Al-Dehneh et al., 1997; Ouellet et al., 2002), but because of greater levels of recycling to the lumen of postruminal tissues (Norton et al., 1982; Reynolds and Huntington, 1988; Huntington, 1989), total-tract urea-N recycling may be equal or greater for 
Table 6. Fecal N partitioning using detergent solutions in heifers fed low (LF) or high forage (HF) diets at 4 levels of $\mathrm{N}$ intake [1.00 (Low), 1.67 (MLow), 2.33 (MHigh), 3.00 (High) g of N/kg of $\mathrm{BW}^{0.75}$ per d]

\begin{tabular}{|c|c|c|c|c|c|c|c|c|c|c|c|}
\hline Item & Forage & \multicolumn{4}{|c|}{$\mathrm{N}$ intake } & SE & \multicolumn{5}{|c|}{ Contrasts, $P$-value } \\
\hline \multicolumn{12}{|l|}{ Neutral detergent } \\
\hline \multirow[t]{2}{*}{ Insoluble N, g } & $\mathrm{LF}$ & 7.19 & 11.83 & 10.69 & 13.61 & 0.60 & $<0.01$ & 0.02 & $<0.01$ & 0.07 & 0.13 \\
\hline & $\mathrm{HF}$ & 13.61 & 16.64 & 14.64 & 14.78 & & & & & & \\
\hline \multirow{2}{*}{ Soluble $\mathrm{N}, \mathrm{g} / \mathrm{kg}$ of DMI } & $\mathrm{LF}$ & 5.28 & 5.38 & 5.26 & 5.57 & 0.20 & 0.32 & $<0.01$ & 0.50 & $<0.01$ & 0.68 \\
\hline & $\mathrm{HF}$ & 4.67 & 4.74 & 5.45 & 5.58 & & & & & & \\
\hline \multirow[t]{2}{*}{ Soluble N, \% of fecal N } & $\mathrm{LF}$ & 82.95 & 74.99 & 76.51 & 78.43 & 1.19 & $<0.01$ & 0.91 & $<0.01$ & $<0.01$ & 0.05 \\
\hline & $\mathrm{HF}$ & 71.05 & 67.53 & 73.33 & 73.40 & & & & & & \\
\hline \multirow[t]{2}{*}{ True N digestibility, $\%$} & LF & 91.66 & 92.04 & 94.67 & 96.20 & 0.52 & $<0.01$ & $<0.01$ & 0.08 & $<0.01$ & $<0.01$ \\
\hline & $\mathrm{HF}$ & 83.86 & 88.71 & 92.91 & 94.43 & & & & & & \\
\hline \multicolumn{12}{|l|}{ Acid detergent } \\
\hline Soluble N, g/kg of DMI & $\mathrm{HF}$ & 5.83 & 6.16 & 6.09 & 6.28 & & & & & & \\
\hline \multirow[t]{2}{*}{ Soluble N, \% of fecal N } & $\mathrm{LF}$ & 90.95 & 94.09 & 93.72 & 89.48 & 2.50 & $<0.01$ & 0.08 & 0.46 & 0.20 & 0.18 \\
\hline & $\mathrm{HF}$ & 89.21 & 87.72 & 81.99 & 82.65 & & & & & & \\
\hline \multirow[t]{2}{*}{ True N digestibility, \% } & $\mathrm{LF}$ & 95.53 & 97.81 & 98.57 & 98.42 & 0.85 & $<0.01$ & 0.02 & 0.74 & 0.03 & 0.08 \\
\hline & $\mathrm{HF}$ & 93.80 & 95.46 & 95.17 & 96.53 & & & & & & \\
\hline
\end{tabular}

animals fed HF diets (Norton et al., 1982; Huntington et al., 1996). In reviewing urea recycling data from several sources with steers fed similar levels of digestible $\mathrm{N}$ intake, Lapierre and Lobley (2001) observed that average net urea transfer to the portal-drained viscera was 103 versus $101 \mathrm{mmol} / \mathrm{h}$ for forage or concentrate diets, respectively. Ultimately, alterations in urea production and recycling cannot be evaluated from the results of this experiment; however, from the greater concentration of PUN maintained and the numerically increased excretion of urinary urea-N (UUN) for heifers fed LF, particularly at lower $\mathrm{N}$ intakes, it could be inferred that there is less GIT recycling of urea, greater production of urea, or both for heifers fed LF.

The fraction of $\mathrm{N}$ intake or urea entry rate that is recycled as urea to the GIT has been increased with increasing concentrations of forage in the diet (Norton et al., 1982; Huntington et al., 1996) or with lower levels of dietary $\mathrm{N}$ intake in both cattle (Bunting et al., 1989; Marini and Van Amburgh, 2003; Wickersham et al., 2008) and sheep (Cocimano and Leng, 1967; Bunting et al., 1987; Marini and Van Amburgh, 2005). The alternative mode of removal of urea from the plasma pool is through excretion in urine. As shown in Table 8, although the mass of UUN excreted did not differ significantly between forage levels, the proportion of $\mathrm{N}$ intake that is excreted as UUN is greater for heifers fed LF than HF. This ratio also increased linearly and quadratically with increasing $\mathrm{N}$ intake such that at the highest levels of $\mathrm{N}$ intake, $42 \%$ of $\mathrm{N}$ intake is excreted as UUN.

The observation that a plateau occurs in the UUN excretion to $\mathrm{N}$ intake ratio may indicate that the maximum capacity for the kidney to concentrate UUN had been exceeded. This could also be the inference from the plateau in the UUN concentration, UUN clearance, and the quadratic response in the concentration ratio of UUN:PUN (mg/dL:mg/dL; Table 8) to increasing $\mathrm{N}$ intake. Thus, although the response was rather variable, the urea concentration gradient between urine and plasma was maximized between MLow and MHigh N intake levels for both forage level groups, beyond which PUN concentrations increased at a greater (linear) rate than UUN concentrations (quadratic/plateauing). A quadratic response in the UUN:PUN ratio has been observed previously in sheep offered different levels of $\mathrm{N}$ intake (Cocimano and Leng, 1967), and coinciding alterations in UUN excretion and urine flow has been attributed to UUN becoming a progressively more important osmotic compound as its need for excretion increases (Cocimano and Leng, 1967; Thornton, 1970). This interpretation also seems to be valid for the current experiment; thus, as $\mathrm{N}$ intake increases and greater quantities of UUN need to be removed from circulation, greater quantities of urine were required to be excreted. This interpretation is also consistent with the tendency 
Table 7. Nitrogen distribution in heifers fed low (LF) or high forage (HF) diets at 4 levels of N intake [1.00 (Low), 1.67 (MLow), 2.33 (MHigh), 3.00 (High) $\mathrm{g}$ of $\mathrm{N} / \mathrm{kg}$ of $\mathrm{BW}^{0.75}$ per d]

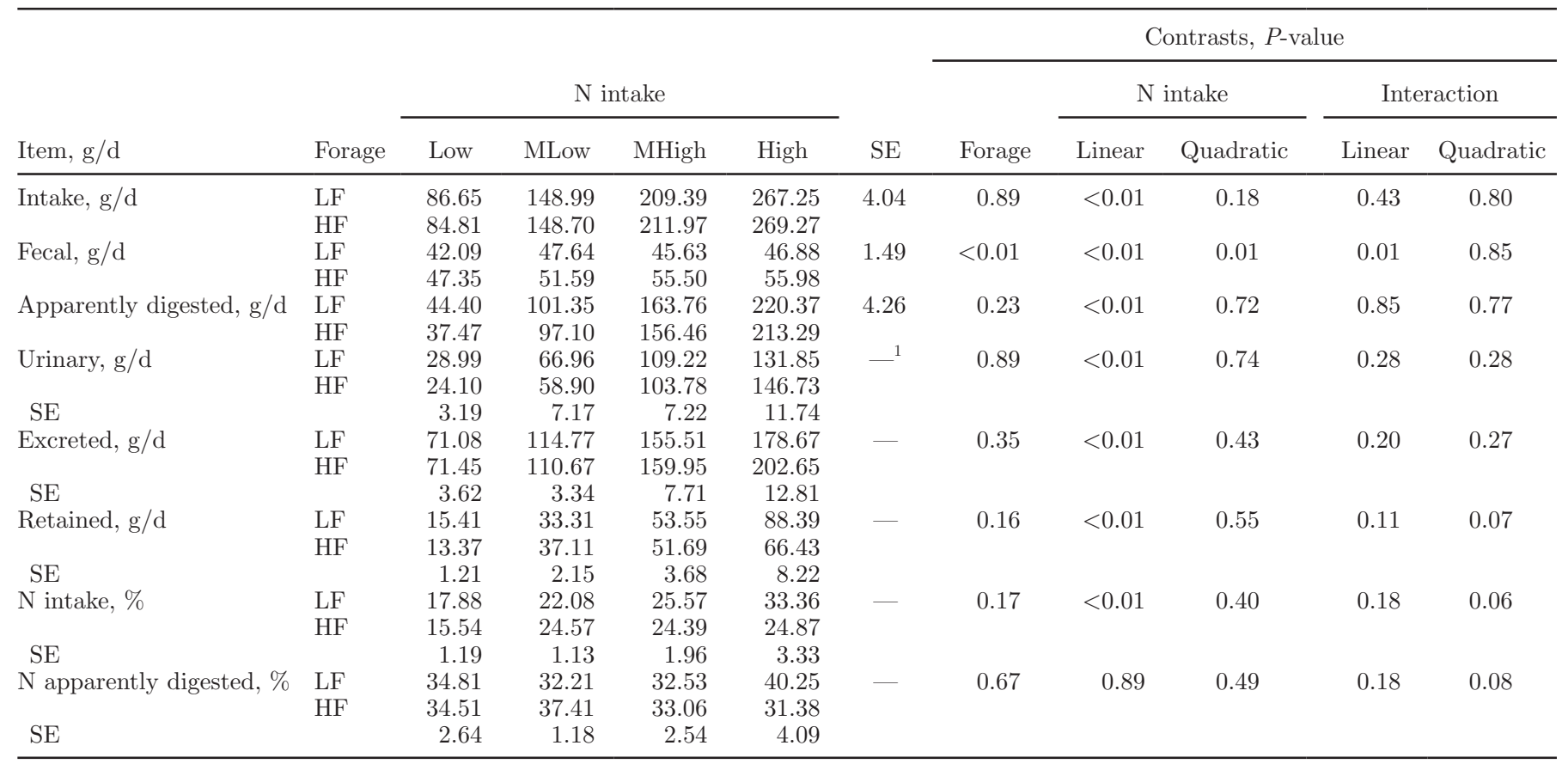

${ }^{1}$ Variance heterogeneity was observed across $\mathrm{N}$ intake levels for indicated items.

of increased kidney mass for sheep fed greater quantities of $\mathrm{N}$ without significant effect on kidney urea transport protein abundance (Marini et al., 2004).

Kohn et al. (2005) determined from regression analysis that urinary $\mathrm{N}$ clearance was $1.3 \mathrm{~L}$ of blood cleared/ (d.kg of BW). Results from the current experiment, when combined and forced though the origin (forage level differences and intercept were not different from $0)$, yield a urinary $\mathrm{N}$ clearance of $1.87( \pm 0.13) \mathrm{L}$ of plasma cleared $/(\mathrm{d} \cdot \mathrm{kg}$ of BW $)$. A constant level of clearance would not be expected, as it has been known for some time that urea clearance varies to some extent with dietary protein intake (Schmidt-Nielsen, 1958). The principle of clearance, while potentially useful to aid urinary $\mathrm{N}$ prediction from a readily accessible sample, applies to specific chemical compounds and equals the product of the concentration of the component in the urine and urine volume divided by the concentration of the component in plasma. All of these measures increase with increasing $\mathrm{N}$ intake, but with differing rates and response functions. As such, due to the increasing proportion of urinary $\mathrm{N}$ excreted as UUN, when urea clearance is measured in the current experiment the result is not a constant as determined through regression for total urinary $\mathrm{N}$, but a volume of plasma that increases linearly and quadratically with increasing $\mathrm{N}$ intake (Table 8). This type of response profile has been observed previously in sheep (Cocimano and Leng,
1967; Sunny et al., 2007) and would also indicate that a limit to UUN concentrating ability had been reached with insufficient increases in urine flow to excrete the additional urea produced.

Urinary creatinine excretion did not differ due to dietary alterations whether expressed as total output or per kilogram of BW, suggesting a constant muscle mass for heifers fed different dietary treatments (Table 8). Creatinine concentration varied inversely with increases in $\mathrm{N}$ intake, but was not different between forage levels. Because of the large range in urine excretion by heifers in this experiment, a relationship between creatinine concentration, BW, and urine volume was evaluated for potential predictive purposes (Figure 4), comparable to relationships defined for dairy cows (Valadares et al., 1999). A close relationship between these variables was confirmed in the current experiment with dairy heifers and indicated an excretion of $24.2 \mathrm{mg}$ of creatinine per $\mathrm{kg}$ of $\mathrm{BW}$. This value is lower than that determined in lactating dairy cows by Valadares et al. (1999), but corresponds closely to values determined with nonlactating cattle (Orskov and MacLeod, 1982; Jones et al., 1990).

\section{Ammonia Volatilization from Manure}

Daily volatilization of $\mathrm{NH}_{3}$ from collected feces and urine is shown in Table 9. Consistent with the results of 


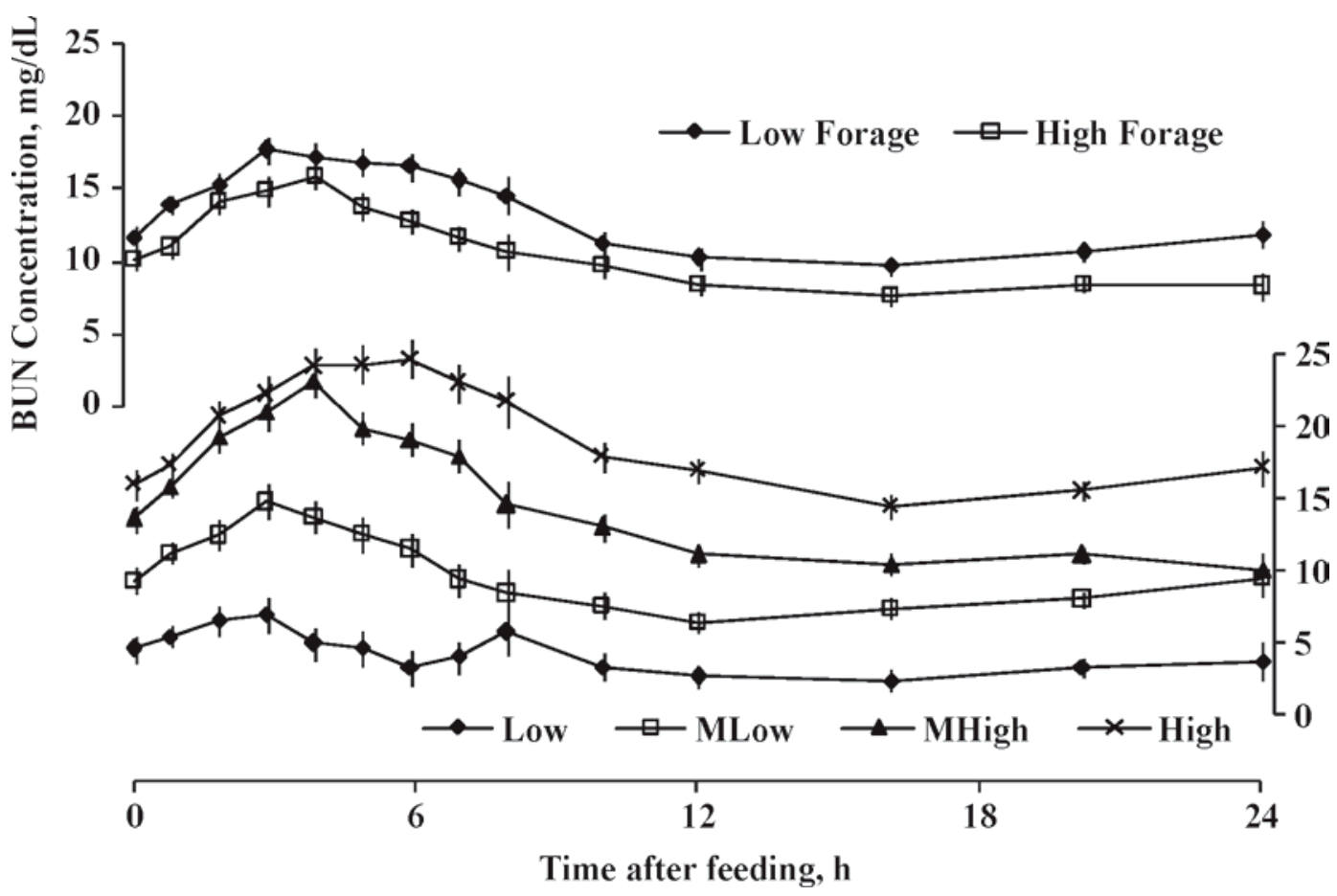

Figure 3. Profile of alterations in BUN after feeding for heifers fed low forage or high forage treatment rations at 4 levels of CP intake [1.00 (Low), 1.67 (MLow), 2.33 (MHigh), $3.00\left(\right.$ High) g of N/kg of BW ${ }^{0.75}$ per d]. The forage $\times$ CP level $\times$ time interaction was not significant, so only the main effects are presented. Standard errors at each time point are indicated by vertical lines $(\mid)$.

Table 8. Urea- $\mathrm{N}$ and creatinine responses in heifers fed low (LF) or high forage (HF) diets at 4 levels of N intake [1.00 (Low), 1.67 (MLow), 2.33 (MHigh), 3.00 (High) g of $\mathrm{N} / \mathrm{kg}$ of $\mathrm{BW}^{0.75}$ per $\left.\mathrm{d}\right]^{1}$

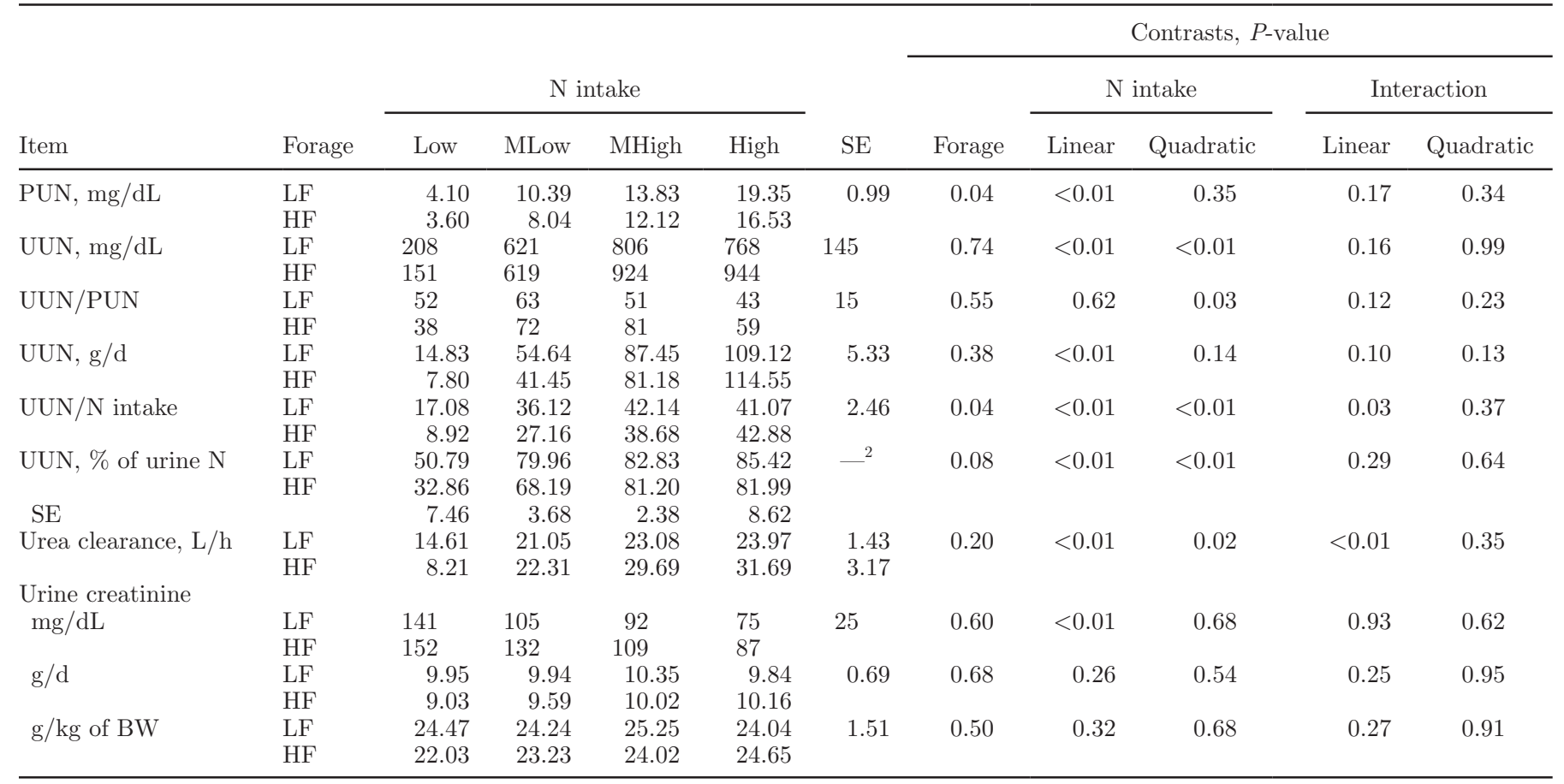

${ }^{1} \mathrm{PUN}=$ plasma urea-N; UUN $=$ urine urea-N.

${ }^{2}$ Variance heterogeneity was observed across $\mathrm{N}$ intake levels. 


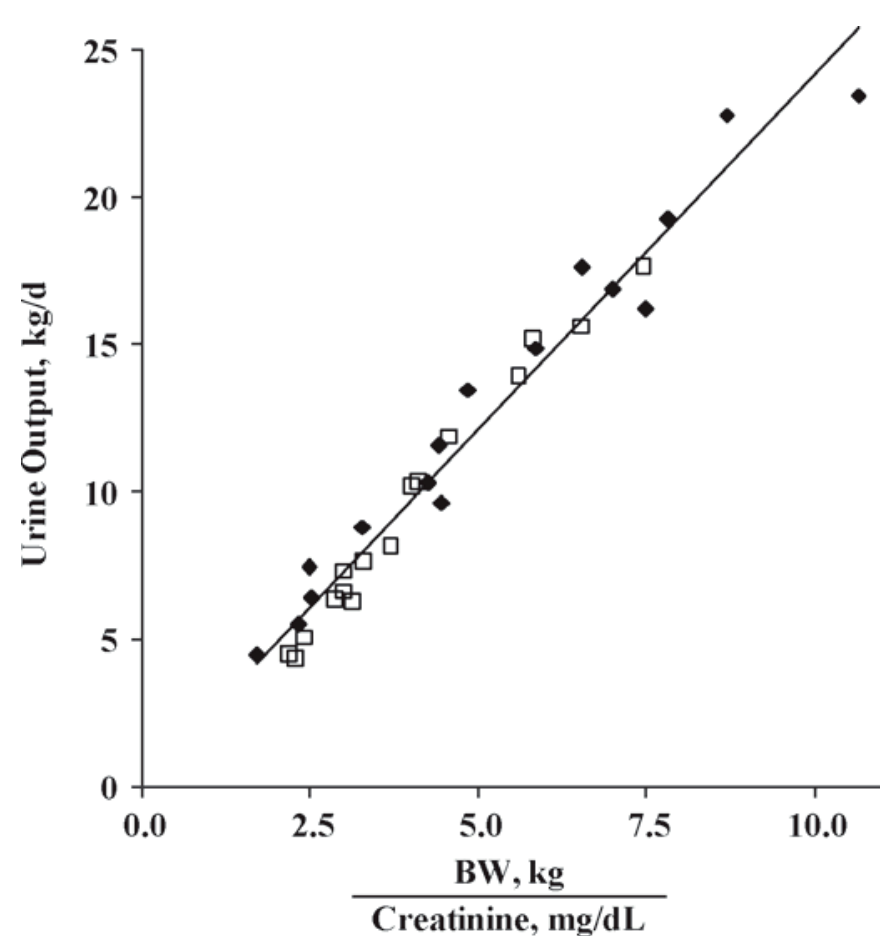

Figure 4. Relationship between BW $(\mathrm{kg})$, urine creatinine concentration $(\mathrm{mg} / \mathrm{dL})$, and urine output $(\mathrm{kg})$ for heifers low forage $(\bullet)$ or high forage $(\square)$ treatment rations at 4 levels of CP intake. Lines were not different between heifers offered different forage levels $(P>0.27)$ or protein levels $(P>0.13)$ and the intercept did not differ significantly from $0(P>0.93)$ when data from all nutritional groups were represented by one linear regression equation: Urine output $(\mathrm{kg} / \mathrm{d})=$ $2.42 \times \mathrm{BW}(\mathrm{kg}) /$ urine creatinine $(\mathrm{mg} / \mathrm{dL})$.

several experiments (James et al., 1999; Frank and Swensson, 2002; Misselbrook et al., 2005), response in $\mathrm{NH}_{3}$ volatilization to additional intake of $\mathrm{N}$ are highly significant. For heifers fed the Low- $\mathrm{N}$ diets, $\mathrm{NH}_{3}$ volatilization was barely detectable throughout the 24 -h period of measurement and these means were not found to differ significantly from zero. In the current experiment, the proportion of total excreted $\mathrm{N}$ that was volatilized as $\mathrm{NH}_{3}-\mathrm{N}$ increased as the $\mathrm{N}$ intake increased because of the greater excretion of UUN; the proportion of UUN volatilized did not differ between diets. Although UUN will be rapidly hydrolyzed in the presence of urease, only $33 \%$ of UUN was observed to be volatilized as $\mathrm{NH}_{3} \mathrm{~N}$ in the current experiment. Urea- $\mathrm{N}$ concentration of the slurry was not measured at the conclusion of the $24-\mathrm{h}$ procedure; however, the low levels of recovery of UUN as volatilized $\mathrm{NH}_{3}-\mathrm{N}$ may indicate that urease activity was limiting, an additional chemical or methodological factor limited $\mathrm{NH}_{3}$ volatilization from the manure slurries, or that defecated bacteria present in the feces were capturing the $\mathrm{NH}_{3}-\mathrm{N}$ from UUN into microbial protein. The possibility or extent of this latter factor is unknown. Ammonia volatilization did not differ between forage levels in the current experiment, regardless of the means of expression. Lascano et al. (2008) determined that $\mathrm{NH}_{3}$ volatilization was unaffected by forage or concentrate diets fed to dairy heifers whether measured from the barn floor or in the laboratory procedure used in the current experiment. Likewise, Hill et al. (2007) observed no significant differences in the manure characteristics measured in that experiment between heifers limit-fed or fed HF. Although wet fecal excretions were lower for heifers fed LF, the similarities in total manure and $\mathrm{N}$ excretion resulted in similar levels of $\mathrm{NH}_{3}$ volatilization between forage levels. Thus, altering levels of dietary forage proved ineffective in reducing $\mathrm{NH}_{3}$ emissions from dairy heifer manure; however, emissions were reduced through reducing dietary $\mathrm{N}$ intake.

\section{Retained $\mathbf{N}$ and $\mathbf{N}$ Efficiency}

Because both fecal and urinary $\mathrm{N}$ excretion increased with increasing $\mathrm{N}$ intake, total $\mathrm{N}$ excretion increased at a greater rate than either response individually, although differences in average $\mathrm{N}$ excretion or in the excretion response to additional $\mathrm{N}$ intake were not significant between forage levels. Consequently, and contrary to the hypothesis of this experiment, retained $\mathrm{N}$ was not different for heifers receiving the different forage levels; retained $\mathrm{N}$ also responded linearly to increasing levels of $\mathrm{N}$ intake. Zanton and Heinrichs (2008a) indicated that over a large range of $\mathrm{N}$ intake, retained $\mathrm{N}$ could be represented as a first-order exponential plateau function where the maximum level of $\mathrm{N}$ retention could be limited by energy level of the diet or the genetic potential of the animal for protein deposition. From the lack of significant quadratic effect due to the increase in $\mathrm{N}$ intake it can be inferred that, for the range of $\mathrm{N}$ intake and level of energy intake used in this experiment, $\mathrm{N}$ intake was limiting $\mathrm{N}$ retention and not energy intake or genetic potential. Given that these heifers were limit-fed diets for ADG $(802 \mathrm{~g} / \mathrm{d}$ for $\mathrm{LF}$ and $787 \mathrm{~g} / \mathrm{d}$ for HF; SE: $39 \mathrm{~g} / \mathrm{d}, P>0.78)$ that are much lower than maximum attainable ADG, it would not be expected that genetic potential would limit the retention of $\mathrm{N}$. However, the divergence of retained $\mathrm{N}$ response at High $\mathrm{N}$ intake resulted in a tendency for a differential quadratic response $(P<0.07)$, possibly indicating a movement toward an energy limitation for heifers fed HF at this level of $\mathrm{N}$ intake that does not occur for heifers fed LF. However, the variability in response at this level of $\mathrm{N}$ intake without greater levels of $\mathrm{N}$ intake to confirm the accuracy of the value, the lack of significant effect, and the impractically high level of $\mathrm{N}$ intake required to achieve this divergence in response 
Table 9. Ammonia volatilization from heifers fed low (LF) or high forage (HF) diets at 4 levels of N intake [1.00 (Low), 1.67 (MLow), 2.33 (MHigh), 3.00 (High) $\mathrm{g}$ of $\mathrm{N} / \mathrm{kg}$ of $\mathrm{BW}^{0.75}$ per d $]^{1}$

\begin{tabular}{|c|c|c|c|c|c|c|c|c|c|c|c|}
\hline Item & Forage & & & & & & \multicolumn{5}{|c|}{ Contrasts, $P$-value } \\
\hline \multicolumn{12}{|l|}{$\mathrm{NH}_{3}$ volatilization } \\
\hline $\mathrm{mg} / \mathrm{g}$ of manure & $\begin{array}{l}\mathrm{LF} \\
\mathrm{HF}\end{array}$ & $\begin{array}{l}0.29^{*} \\
0.15^{*}\end{array}$ & $\begin{array}{l}1.07 \\
0.97\end{array}$ & $\begin{array}{l}1.90 \\
1.75\end{array}$ & $\begin{array}{l}1.94 \\
1.70\end{array}$ & 0.26 & 0.57 & $<0.01$ & 0.99 & 0.16 & 0.42 \\
\hline \multirow[t]{2}{*}{$\mathrm{NH}_{3}-\mathrm{N} / \mathrm{N}$ excreted, $\%$} & $\mathrm{LF}$ & 5.43 & 13.93 & 18.86 & 19.11 & - & 0.69 & $<0.01$ & $<0.01$ & 0.85 & 0.21 \\
\hline & $\mathrm{HF}$ & $3.63^{*}$ & 14.29 & 21.06 & 16.09 & & & & & & \\
\hline $\mathrm{SE}$ & & 1.35 & 3.33 & 0.70 & 1.42 & & & & & & \\
\hline \multirow{2}{*}{$\mathrm{NH}_{3}-\mathrm{N} / \mathrm{UUN}$ excreted, $\%$} & $\mathrm{LF}$ & 25.30 & 28.86 & 36.12 & 31.63 & - & 0.34 & 0.63 & 0.18 & 0.57 & 0.53 \\
\hline & $\mathrm{HF}$ & 31.99 & 38.26 & 44.27 & 29.53 & & & & & & \\
\hline $\mathrm{SE}$ & & 10.49 & 9.60 & 2.66 & 3.15 & & & & & & \\
\hline
\end{tabular}

${ }^{1}$ Volatilization was determined from a daily composite of manure slurry for $24 \mathrm{~h}$ using a bench-top, steady-state (dynamic) flux chamber.

*Values are not different from zero.

substantially reduce the confidence and potential importance of this inference.

Although the proportion of $\mathrm{N}$ excreted in the feces was greater for heifers fed HF and as this difference was largely counterbalanced by the increased excretion of urine $\mathrm{N}$ in heifers fed LF, the efficiency of intake $\mathrm{N}$ retention did not differ between forage levels (Table 5 ). The efficiency of intake $\mathrm{N}$ retention increased with increasing $\mathrm{N}$ intake, however. This efficiency was maximized for heifers fed $\mathrm{HF}$ at $\sim 24.5 \%$ when $\mathrm{N}$ intake was at or greater than the MLow level. This level of efficiency approximates the level of efficiency observed by Zanton and Heinrichs (2008b) when an HF diet was limit-fed at levels of DMI greater or equal to $1.50 \%$ of BW as well as the average maximum level of efficiency observed in a literature analysis by Zanton and Heinrichs (2008a), although individual experiment and diet combinations obtained greater levels of efficiency. In contrast, heifers fed $\mathrm{LF}$ retained intake $\mathrm{N}$ at similar levels of efficiency as $\mathrm{HF}$ until $\mathrm{N}$ intake increased to the High level of $\mathrm{N}$ intake where the efficiency of retaining $\mathrm{N}$ intake continued to increase numerically. The tendency for a quadratic interaction resulted from the plateau observed for heifers fed HF with essentially no nonlinearity observed for LF. No differences in apparently digested $\mathrm{N}$ retention efficiency were observed in the current experiment, which averaged $34.52 \%$. Consequently, under the conditions of the current experiment with heifers limit-fed LF or HF over a range on $\mathrm{N}$ intakes, $\mathrm{N}$ retention and the efficiency of $\mathrm{N}$ retention did not differ between heifers fed diets containing different forage levels.

The lack of response in $\mathrm{N}$ retention and efficiency to altered levels of forage observed in this experiment is contrary to the responses observed in several other experiments (Murphy et al., 1994; Driedger and Loerch, 1999; Moody et al., 2007). The cause of this discrepancy cannot be confidently determined; however, the provision of isoenergetic and isonitrogenous diets in the current experiment is likely a significant contributor. Additional factors that may contribute to the differences between experiments are the quality, proportion, and type of forage included in the diets, the level and quality of rumen undegradable protein, as well as animal factors such as age and growth potential. Although different combinations of forage and concentrates may alter the absolute levels of $\mathrm{N}$ retention and efficiencies observed, under the conditions of the current experiment, in which $\mathrm{HF}$ and $\mathrm{LF}$ diets were given under isoenergetic and isonitrogenous conditions across a wide range of $\mathrm{N}$ intakes, no alterations in $\mathrm{N}$ retention or efficiency of $\mathrm{N}$ retention were observed.

\section{CONCLUSIONS}

When LF or HF diets were limit-fed to growing dairy heifers, OM digestibility was greater for heifers fed LF due to the inclusion of more digestible dietary constituents because the digestibilities of the constituents individually were equal or lower for LF than HF. Organic matter digestibility was improved by greater $\mathrm{N}$ intake, but the maximum level of $\mathrm{OM}$ digestibility required greater intake of $\mathrm{N}$ for heifers fed LF than HF. Manure excretion and $\mathrm{NH}_{3}$ volatilization were not different between forage levels, but were increased with increasing $\mathrm{N}$ intake because of greater levels of urine and total $\mathrm{N}$ excretion. Differences in $\mathrm{N}$ partitioning observed between forage levels were limited to differences in apparent and true digestibility. Thus, the significant reduction observed in fecal $\mathrm{N}$ excretion for LF was coun- 
terbalanced by numerical increases in urinary $\mathrm{N}$ excretion so that total $\mathrm{N}$ excretion and retention were not different between forage levels. As $\mathrm{N}$ intake increased beyond MLow, there was evidence for maximized UUN concentrating ability, which may contribute to increased urine output. Increasing $\mathrm{N}$ intake increased all aspects of $\mathrm{N}$ partitioning and efficiency evaluated except for the proportion of apparently digested $\mathrm{N}$ that was retained, which was not affected by any of the dietary alterations made in this experiment. There is no evidence that would support increasing $\mathrm{N}$ intake above MLow $(1.67 \mathrm{~g}$ of $\mathrm{N} / \mathrm{kg}$ of $\mathrm{BW}^{0.75}$ or approximately $13 \% \mathrm{CP}$ ), because improvements in $\mathrm{N}$ retention do not come at increased levels of efficiency, and manure and $\mathrm{N}$ output as well as $\mathrm{NH}_{3}$ emissions increase. In conclusion, contrary to the hypothesis of this experiment, $\mathrm{N}$ efficiency was not increased for dairy heifers fed a LF diet compared with a HF diet when intakes of $\mathrm{N}$ and energy were held constant between groups. Thus, limit-fed dairy heifers should receive the same quantity of $\mathrm{N}$ regardless of the forage level in the ration.

\section{REFERENCES}

Al-Dehneh, A., J. T. Huber, R. Wanderley, C. B. Theurer, M. Pessarakli, and D. DeYoung. 1997. Incorporation of recycled urea-N into ruminal bacteria flowing to the small intestine of dairy cows fed a high-grain or high-forage diet. Anim. Feed Sci. Technol. 68:327-338.

AOAC. 1990. Official Methods of Analysis. 15th ed. AOAC, Arlington, VA.

Atasoglu, C., A. Y. Guliye, and R. J. Wallace. 2004. Use of stable isotopes to measure de novo synthesis and turnover of amino acid-C and $-\mathrm{N}$ in mixed micro-organisms from the sheep rumen in vitro. Br. J. Nutr. 91:253-261.

Attaix, D., E. Aurousseau, G. Bayle, D. Rosolowskahuszcz, and M. Arnal. 1988. Respective influences of age and weaning on skeletal and visceral muscle protein-synthesis in the lamb. Biochem. J. 256:791-795.

Bach Knudsen, K. E. 1997. Carbohydrate and lignin contents of plant materials used in animal feeding. Anim. Feed Sci. Technol. 67:319-338.

Bannink, A., H. Valk, and A. M. Van Vuuren. 1999. Intake and excretion of sodium, potassium, and nitrogen and the effects on urine production by lactating dairy cows. J. Dairy Sci. 82:10081018.

Biddle, G. N., J. L. Evans, and J. R. Trout. 1975. Labile nitrogen reserves in the ruminant. Metabolic changes in growing cattle employing a nitrogen depletion-repletion treatment. J. Nutr. 105:1578-1583.

Bunting, L. D., J. A. Boling, and C. T. MacKown. 1989. Effect of dietary protein level on nitrogen metabolism in the growing bovine: I. Nitrogen recycling and intestinal protein supply in calves. J. Anim. Sci. 67:810-819.

Bunting, L. D., J. A. Boling, C. T. MacKown, and R. B. Muntifering. 1987. Effect of dietary protein level on nitrogen metabolism in lambs: Studies using ${ }^{15} \mathrm{~N}$-nitrogen. J. Anim. Sci. 64:855-867.

Cameron, M. R., T. H. Klusmeyer, G. L. Lynch, J. H. Clark, and D. R. Nelson. 1991. Effects of urea and starch on rumen fermentation, nutrient passage to the duodenum, and performance of cows. J. Dairy Sci. 74:1321-1336.

Cocimano, M. R., and R. A. Leng. 1967. Metabolism of urea in sheep. Br. J. Nutr. 21:353-371.
Colucci, P. E., G. K. MacLeod, W. L. Grovum, L. W. Cahill, and I. McMillan. 1989. Comparative digestion in sheep and cattle fed different forage to concentrate ratios at high and low intakes. J. Dairy Sci. 72:1774-1785.

Driedger, L. J., and S. C. Loerch. 1999. Limit-feeding corn as an alternative to hay reduces manure and nutrient output by Holstein cows. J. Anim. Sci. 77:967-972.

Eschenlauer, S. C. P., N. McKain, N. D. Walker, N. R. McEwan, C. J. Newbold, and R. J. Wallace. 2002. Ammonia production by ruminal microorganisms and enumeration, isolation, and characterization of bacteria capable of growth on peptides and amino acids from the sheep rumen. Appl. Environ. Microbiol. 68:4925-4931.

Fellner, V., M. F. Weiss, A. T. Belo, R. L. Belyea, F. A. Martz, and A. H. Orma. 1988. Urine cup for collection of urine from cows. J. Dairy Sci. 71:2250-2255.

Frank, B., and C. Swensson. 2002. Relationship between content of crude protein in rations for dairy cows and milk yield, concentration of urea in milk and ammonia emissions. J. Dairy Sci. 85:1829 1838 .

Gabler, M. T., and A. J. Heinrichs. 2003. Effects of increasing dietary protein on nutrient utilization in heifers. J. Dairy Sci. 86:21702177 .

Hill, S. R., K. F. Knowlton, R. E. James, R. E. Pearson, G. L. Bethard, and K. J. Pence. 2007. Nitrogen and phosphorus retention and excretion in late-gestation dairy heifers. J. Dairy Sci. 90:56345642 .

Hoffman, P. C., N. M. Esser, L. M. Bauman, S. L. Denzine, M. Engstrom, and H. Chester-Jones. 2001. Short communication: Effect of dietary protein on growth and nitrogen balance of Holstein heifers. J. Dairy Sci. 84:843-847.

Hoffman, P. C., C. R. Simson, and M. Wattiaux. 2007. Limit feeding of gravid Holstein heifers: Effect on growth, manure nutrient excretion, and subsequent early lactation performance. J. Dairy Sci. 90:946-954.

Hristov, A. N., J. K. Ropp, K. L. Grandeen, S. Abedi, R. P. Etter, A. Melgar, and A. E. Foley. 2005. Effect of carbohydrate source on ammonia utilization in lactating dairy cows. J. Anim. Sci. 83:408-421.

Huntington, G. B. 1989. Hepatic urea synthesis and site and rate of urea removal from blood of beef steers fed alfalfa hay or a high concentrate diet. Can. J. Anim. Sci. 69:215-223.

Huntington, G. B., E. J. Zetina, J. M. Whitt, and W. Potts. 1996. Effects of dietary concentrate level on nutrient absorption, liver metabolism, and urea kinetics of beef steers fed isonitrogenous and isoenergetic diets. J. Anim. Sci. 74:908-916.

Ipharraguerre, I. R., J. H. Clark, and D. E. Freeman. 2005. Varying protein and starch in the diet of dairy cows. I. Effects on ruminal fermentation and intestinal supply of nutrients. J. Dairy Sci. 88:2537-2555.

James, T., D. Meyer, E. Esparza, E. J. Depeters, and H. PerezMonti. 1999. Effects of dietary nitrogen manipulation on ammonia volatilization from manure from Holstein heifers. J. Dairy Sci. 82:2430-2439.

Jones, S. J., D. L. Starkey, C. R. Calkins, and J. D. Crouse. 1990. Myofibrillar protein-turnover in feed-restricted and realimented beef-cattle. J. Anim. Sci. 68:2707-2715.

Kennedy, P. M. 1980. Effects of dietary sucrose and the concentrations of plasma urea and rumen ammonia on the degradation of urea in the gastrointestinal-tract of cattle. Br. J. Nutr. 43:125-140.

Kirkpatrick, D. E., R. W. J. Steen, and E. F. Unsworth. 1997. The effect of differing forage:concentrate ratio and restricting feed intake on the energy and nitrogen utilization by beef cattle. Livest. Prod. Sci. 51:151-164.

Kohn, R. A., M. M. Dinneen, and E. Russek-Cohen. 2005. Using blood urea nitrogen to predict nitrogen excretion and efficiency of nitrogen utilization in cattle, sheep, goats, horses, pigs, and rats. J. Anim. Sci. 83:879-889.

Kume, S., K. Nonaka, T. Oshita, T. Kozakai, and H. Hirooka. 2008. Effects of urinary excretion of nitrogen, potassium and sodium on urine volume in dairy cows. Livest. Sci. 115:28-33. 
Lapierre, H., and G. E. Lobley. 2001. Nitrogen recycling in the ruminant: A review. J. Dairy Sci. 84(E Suppl.):E223-E236.

Lascano, G. J., G. I. Zanton, M. L. Moody, P. A. Topper, E. F. Wheeler, and A. J. Heinrichs. 2008. Effect of changing the ratio of forage to concentrate on ammonia emissions by dairy heifers. J. Dairy Sci. 91:4301-4306.

Licitra, G., T. M. Hernandez, and P. J. Van Soest. 1996. Standardization of procedures for nitrogen fractionation of ruminant feeds. Anim. Feed Sci. Technol. 57:347-358.

Lobley, G. E., D. M. Bremner, and G. Zuur. 2000. Effects of diet quality on urea fates in sheep as assessed by refined, non-invasive $\left[{ }^{15} \mathrm{~N}^{15} \mathrm{~N}\right]$ urea kinetics. Br. J. Nutr. 84:459-468.

Lobley, G. E., X. Z. Shen, G. W. Le, D. M. Bremner, E. Milne, A. G. Calder, S. E. Anderson, and N. Dennison. 2003. Oxidation of essential amino acids by the ovine gastrointestinal tract. Br. J. Nutr. 89:617-629.

Lobley, G. E., P. J. M. Weijs, A. Connell, A. G. Calder, D. S. Brown, and E. Milne. 1996. The fate of absorbed and exogenous ammonia as influenced by forage or forage-concentrate diets in growing sheep. Br. J. Nutr. 76:231-248.

Marini, J. C., J. D. Klein, J. M. Sands, and M. E. Van Amburgh. 2004. Effect of nitrogen intake on nitrogen recycling and urea transporter abundance in lambs. J. Anim. Sci. 82:1157-1164.

Marini, J. C., and M. E. Van Amburgh. 2003. Nitrogen metabolism and recycling in Holstein heifers. J. Anim. Sci. 81:545-552.

Marini, J. C., and M. E. Van Amburgh. 2005. Partition of nitrogen excretion in urine and the feces of Holstein replacement heifers. J. Dairy Sci. 88:1778-1784.

Mason, V. C. 1969. Some observations on distribution and origin of nitrogen in sheep faeces. J. Agric. Sci. 73:99-111.

Misselbrook, T. H., J. M. Powell, G. A. Broderick, and J. H. Grabber. 2005. Dietary manipulation in dairy cattle: Laboratory experiments to assess the influence on ammonia emissions. J. Dairy Sci. 88:1765-1777.

Moody, M. L., G. I. Zanton, J. M. Daubert, and A. J. Heinrichs. 2007. Nutrient utilization of differing forage-to-concentrate ratios by growing Holstein heifers. J. Dairy Sci. 90:5580-5586.

Murphy, T. A., S. C. Loerch, and F. E. Smith. 1994. Effects of feeding high-concentrate diets at restricted intakes on digestibility and nitrogen metabolism in growing lambs. J. Anim. Sci. 72:15831590 .

NRC. 2001. Nutrient Requirements of Dairy Cattle. 7th ed. Natl. Acad. Press, Washington, DC.

Norton, B. W., J. B. MacKintosh, and D. G. Armstrong. 1982. Urea synthesis and degradation in sheep given pelleted grass diets containing flaked barley. Br. J. Nutr. 48:249-264.

Odle, J., and D. M. Schaefer. 1987. Influence of rumen ammonia concentration on the rumen degradation rates of barley and maize. Br. J. Nutr. 57:127-138.

Orskov, E. R., C. Fraser, V. C. Mason, and S. O. Mann. 1970 Influence of starch digestion in large intestine of sheep on caecal fermentation, caecal microflora and faecal nitrogen excretion. Br. J. Nutr. 24:671-682.

Orskov, E. R., and N. A. MacLeod. 1982. The determination of the minimal nitrogen excretion in steers and dairy cows and its physiological and practical implications. Br. J. Nutr. 47:625636.

Ouellet, D. R., M. Demers, G. Zuur, G. E. Lobley, J. R. Seoane, J. V. Nolan, and H. Lapierre. 2002. Effect of dietary fiber on endogenous nitrogen flows in lactating dairy cows. J. Dairy Sci. 85:3013-3025.

Reynolds, C. K., and G. B. Huntington. 1988. Partition of portaldrained visceral net flux in beef steers. 1. Blood flow and net flux of oxygen, glucose and nitrogenous compounds across stomach and post stomach tissues. Br. J. Nutr. 60:539-551.

Reynolds, C. K., H. F. Tyrrell, and P. J. Reynolds. 1991a. Effects of diet forage-to-concentrate ratio and intake on energy metabolism in growing beef heifers - Net nutrient metabolism by visceral tissues. J. Nutr. 121:1004-1015.
Reynolds, C. K., H. F. Tyrrell, and P. J. Reynolds. 1991b. Effects of diet forage-to-concentrate ratio and intake on energy-metabolism in growing beef heifers-Whole-body energy and nitrogen balance and visceral heat-production. J. Nutr. 121:994-1003.

Richards, C. J., A. F. Branco, D. W. Bohnert, G. B. Huntington, M. Macari, and D. L. Harmon. 2002. Intestinal starch disappearance increased in steers abomasally infused with starch and protein. J. Anim. Sci. 80:3361-3368.

Schmidt-Nielsen, B. 1958. Urea excretion in mammals. Physiol. Rev. $38: 139-168$.

Schroeder, G. F., and E. C. Titgemeyer. 2008. Interaction between protein and energy supply on protein utilization in growing cattle: A review. Livest. Sci. 114:1-10.

Seal, C. J., D. S. Parker, and D. P. J. Avery. 1992. The effect of forage and forage-concentrate diets on rumen fermentation and metabolism of nutrients by the mesenteric-drained and portaldrained viscera in growing steers. Br. J. Nutr. 67:355-370.

Stein, H. H., B. Seve, M. F. Fuller, P. J. Moughan, and C. F. M de Lange. 2007. Invited review: Amino acid bioavailability and digestibility in pig feed ingredients: Terminology and application. J. Anim. Sci. 85:172-180.

Streeter, M. N., and M. J. Mathis. 1995. Effect of supplemental fish meal protein on site and extent of digestion in beef steers. J. Anim. Sci. 73:1196-1201.

Sunny, N. E., S. L. Owens, R. L. Baldwin, S. W. El-Kadi, R. A Kohn, and B. J. Bequette. 2007. Salvage of blood urea nitrogen in sheep is highly dependent on plasma urea concentration and the efficiency of capture within the digestive tract. J. Anim. Sci. 85:1006-1013.

Szanyiova, M., L. Leng, and S. Faix. 1995. Partition of nitrogenous substances in the urine of sheep on different dietary protein intakes. Vet. Res. 26:27-31.

Taniguchi, K., G. B. Huntington, and B. P. Glenn. 1995. Net nutrient flux by visceral tissues of beef steers given abomasal and ruminal infusions of casein and starch. J. Anim. Sci. 73:236-249.

Thornton, R. F. 1970. Factors affecting urinary excretion of urea nitrogen in cattle. 2. Plasma urea nitrogen concentration. Aust. J. Agric. Res. 21:145-152.

Thornton, R. F., P. R. Bird, M. Somers, and R. J. Moir. 1970. Urea excretion in ruminants. 3. Role of hind-gut (caecum and colon) Aust. J. Agric. Res. 21:345-354.

Valadares, R. F. D., G. A. Broderick, S. C. V. Filho, and M. K. Clayton. 1999. Effect of replacing alfalfa silage with high moisture corn on ruminal protein synthesis estimated from excretion of total purine derivatives. J. Dairy Sci. 82:2686-2696.

Van Soest, P. J., J. B. Robertson, and B. A. Lewis. 1991. Methods for dietary fiber, neutral detergent fiber, and nonstarch polysaccharides in relation to animal nutrition. J. Dairy Sci. 74:3583-3597.

Veira, D. M., G. K. Macleod, J. H. Burton, and J. B. Stone. 1980 Nutrition of the weaned Holstein calf. 2. Effect of dietary protein level on nitrogen balance, digestibility and feed intake. J. Anim. Sci. 50:945-951.

Virtanen, A. I. 1966. Milk production of cows on protein-free feed Science 153:1603-1614.

Wickersham, T. A., E. C. Titgemeyer, R. C. Cochran, and E. E. Wickersham. 2008. Effect of undegradable intake protein supplementation on urea kinetics and microbial use of recycled urea in steers consuming low-quality forage. Br. J. Nutr. 23:1-8

Zanton, G. I., and A. J. Heinrichs. 2007. The effects of controlled feeding of a high-forage or high-concentrate ration on heifer growth and first-lactation milk production. J. Dairy Sci. 90:3388-3396.

Zanton, G. I., and A. J. Heinrichs. 2008a. Analysis of nitrogen utilization and excretion in growing dairy cattle. J. Dairy Sci. 91:1519-1533.

Zanton, G. I., and A. J. Heinrichs. 2008b. Rumen digestion and nutritional efficiency of dairy heifers limit-fed a high forage ration to four levels of dry matter intake. J. Dairy Sci. 91:3579-3588. 